\title{
Drilling, Construction, Water-Level, and Water-Quality Information for the Kualapuu Deep Monitor Well 4-0800-01, Molokai, Hawaii
}

U.S. GEOLOGICAL SURVEY

Open-File Report 01-350

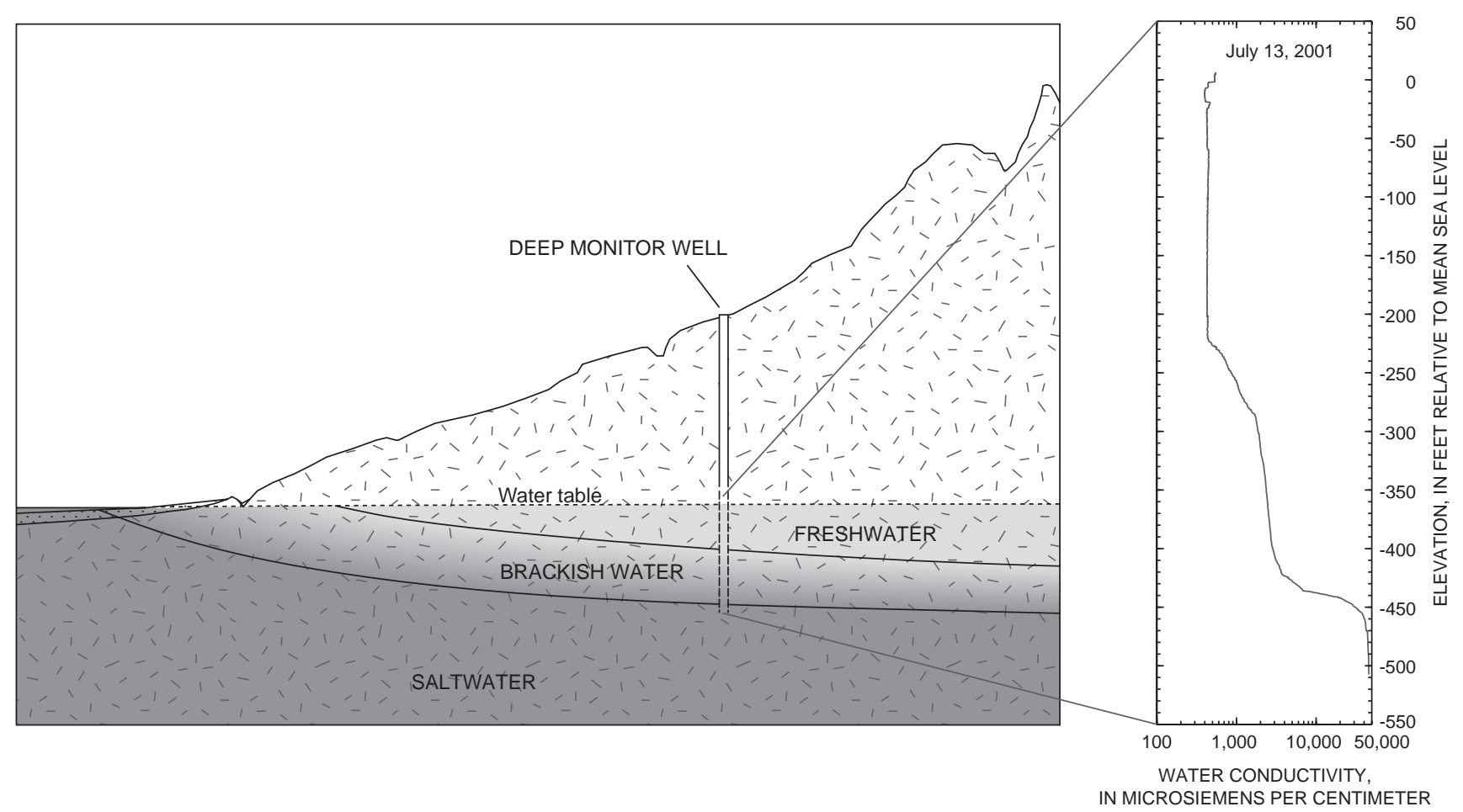

Prepared in cooperation with the STATE OF HAWAII DEPARTMENT OF HAWAIIAN HOME LANDS and MAUI COUNTY DEPARTMENT OF WATER SUPPLY 


\section{Drilling, Construction, Water-Level, and Water-Quality Information for the Kualapuu Deep Monitor Well 4-0800-01, Molokai, Hawaii}

By Delwyn S. Oki, U.S. Geological Survey

Glenn R. Bauer, State of Hawaii Commission on Water Resource Management

U.S. GEOLOGICAL SURVEY

Open-File Report 01-350

Prepared in cooperation with the STATE OF HAWAII DEPARTMENT OF HAWAIIAN HOME LANDS and MAUI COUNTY DEPARTMENT OF WATER SUPPLY 


\section{U.S. DEPARTMENT OF THE INTERIOR \\ GALE A. NORTON, Secretary}

\section{U.S. GEOLOGICAL SURVEY}

Charles G. Groat, Director

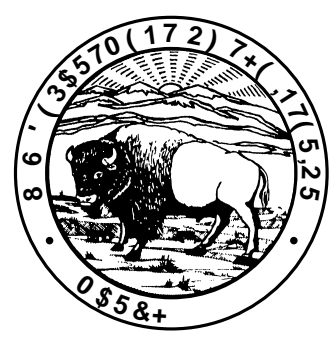

The use of firm, trade, and brand names in this report is for identification purposes only and does not constitute endorsement by the U.S. Geological Survey.

For additional information write to:

District Chief

U.S. Geological Survey

677 Ala Moana Blvd., Suite 415

Honolulu, HI 96813
Copies of this report can be purchased from:

U.S. Geological Survey Branch of Information Services Box 25286

Denver, CO 80225-0286 


\section{CONTENTS}

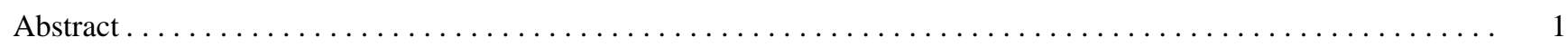

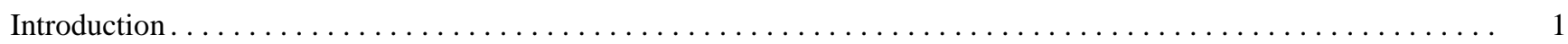

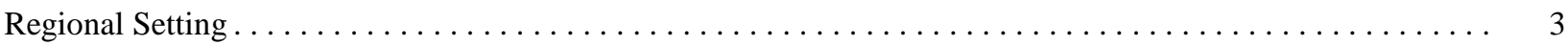

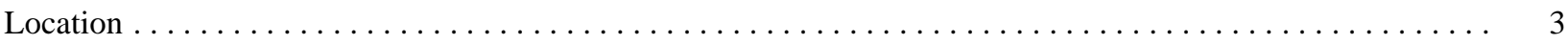

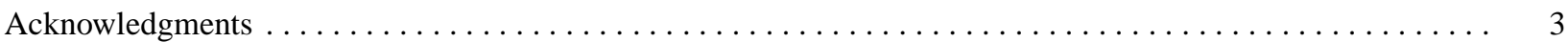

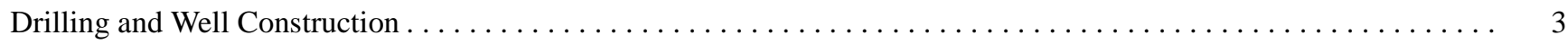

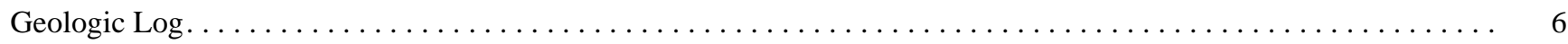

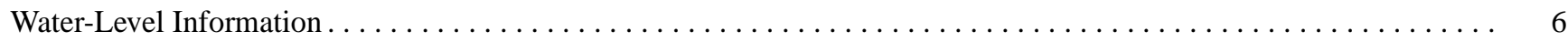

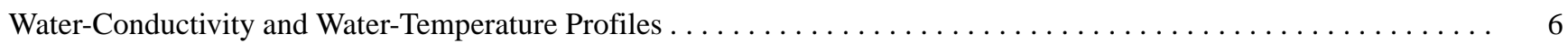

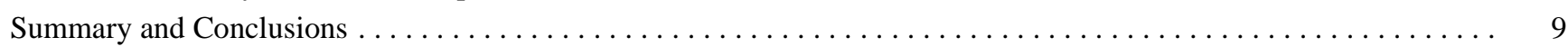

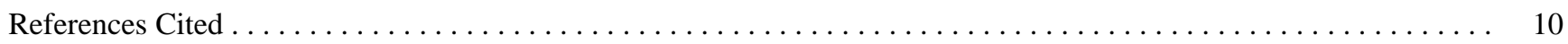

\section{FIGURES}

1-2. Maps showing:

1. Geographic features, island of Molokai, Hawaii, and locations of the Kualapuu area and the Kualapuu

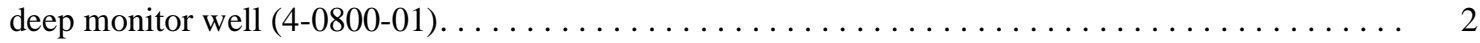

2. Generalized surficial geology of Molokai, Hawaii $\ldots \ldots \ldots \ldots \ldots \ldots \ldots$

3. Drawing showing construction details for the Kualapuu deep monitor well (4-0800-01), Molokai, Hawaii . . 7

4. Graph showing water-conductivity and -temperature profiles measured in the Kualapuu deep monitor well (4-0800-01) on April 3 and July 13, 2001, Molokai, Hawaii $\ldots \ldots \ldots \ldots \ldots$

\section{TABLES}

1. Location, elevation, and State number of the Kualapuu deep monitor well, Molokai, Hawaii . . . . . . . . 5

2. Summary of construction of the Kualapuu deep monitor well (4-0800-01), Molokai, Hawaii . . . . . . . . . . 5

3. Lithologic descriptions of rock cuttings from the Kualapuu deep monitor well (4-0800-01), Molokai, Hawaii. . . 11

4. Water-level measurements made during the period from February 1 to July 13, 2001, Kualapuu deep monitor well

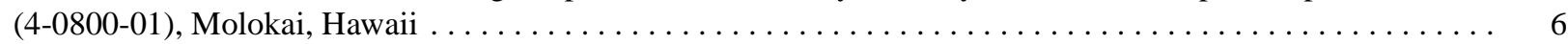


iv Drilling, Construction, Water-Level, and Water-Quality Information for the Kualapuu Deep Monitor Well 


\title{
Drilling, Construction, Water-Level, and Water-Quality Information for the Kualapuu Deep Monitor Well 4-0800-01, Molokai, Hawaii
}

\author{
By Delwyn S. Oki, U.S. Geological Survey \\ Glenn R. Bauer, State of Hawaii Commission on Water Resource Management
}

\section{Abstract}

A monitor well was completed in January 2001 by the U.S. Geological Survey in the Kualapuu area of central Molokai, Hawaii that allows for monitoring the thicknesses of the freshwater body and the upper part of the underlying freshwatersaltwater transition zone. The well was drilled in cooperation with the State Department of Hawaiian Home Lands and the Maui County Department of Water Supply, and is located near the area that supplies much of the drinking water on Molokai. The well is at a ground-surface elevation of about 982 feet and penetrated a 1,585-foot section of soil and volcanic rock to a depth of 603 feet below sea level. Prior to casing, a cave-in caused the bottom 55 feet of the well to be filled with rocks originating from a zone above. Thus, the final well depth reported by the driller was 1,530 feet.

Measured water levels in the well during the period from February 1 to July 13, 2001 range from 8.68 to 9.05 feet above sea level. The most recent available water-conductivity profile from July 13, 2001 indicates that the lowest salinity water in the well is in the upper zone from the water table to a depth of about 220 feet below sea level. Below this upper zone, water salinity increases with depth. The water-temperature profile from July 13, 2001 indicates that the lowest temperature water (20.2 degrees Celsius) in the well is located in the upper zone from the water table to a depth of about 200 feet below sea level. Water temperature increases to 24.5 degrees Celsius near the bottom of the measured profile, 507 feet below sea level.

\section{INTRODUCTION}

Management of the ground-water resources of the island of Molokai, Hawaii has been hindered by the uncertainty in the vertical distribution of ground-water salinity in the aquifer in the Kualapuu area (fig. 1), where demand for water is high. [For the purposes of this report, the Kualapuu area corresponds to the Kualapuu aquifer system (State of Hawaii, 1990) as defined by the State of Hawaii Commission on Water Resource Management (CWRM)]. In the State of Hawaii, vertical profiles of water salinity are commonly obtained from deep monitor wells. These profiles are used to estimate the thicknesses of the freshwater body and underlying freshwater-saltwater transition zone. Because of the need for information on the thicknesses of the freshwater body and freshwater-saltwater transition zone, the U.S. Geological Survey (USGS), in cooperation with the State of Hawaii Department of Hawaiian Home Lands (DHHL) and the Maui County Department of Water Supply (DWS), drilled a deep monitor well (State well number 4-0800-01) in the Kualapuu area between February 2000 and January 2001. This report documents (1) the well location, (2) drilling and wellconstruction information from the drillers, (3) geologic descriptions of the rock cuttings brought to the surface during drilling, (4) available water-level information, and (5) available information from water-conductivity and -temperature profiles from the deep monitor well. 


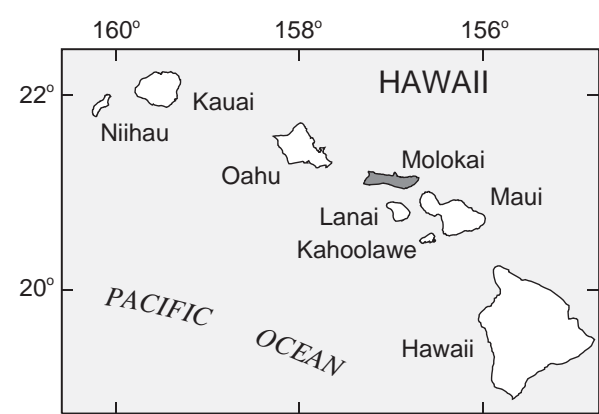

LOCATION MAP

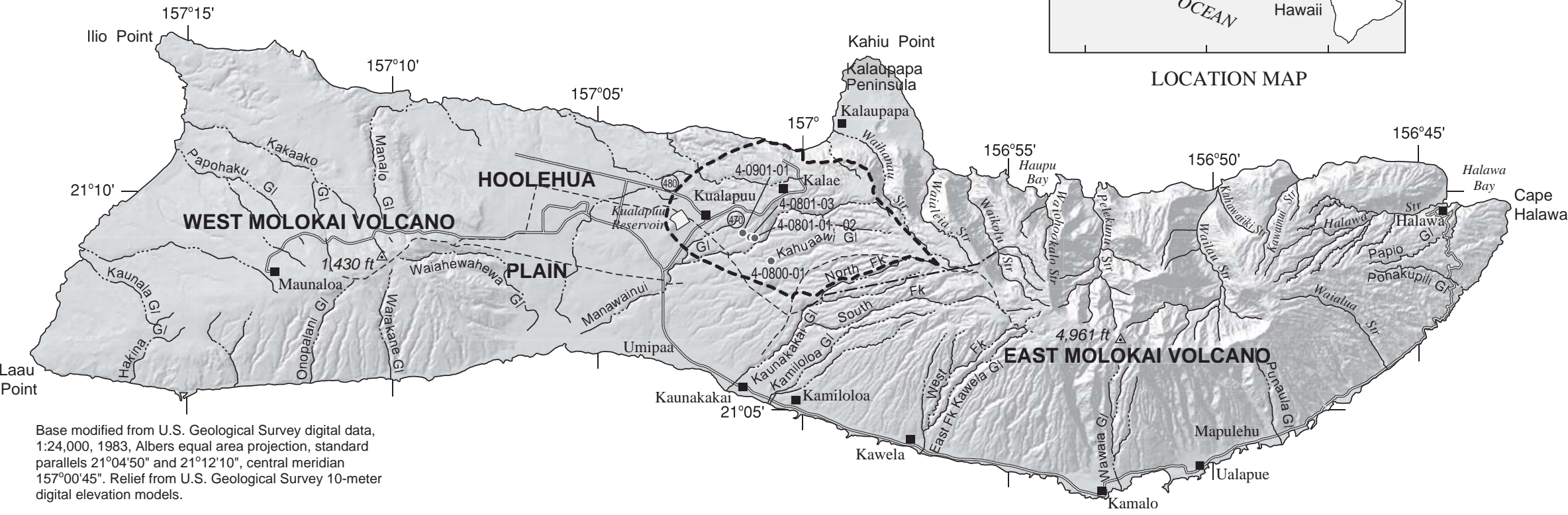

EXPLANATION

------- MOLOKAI IRRIGATION SYSTEM PIPELINE

-.--.-_. MOLOKAI IRRIGATION SYSTEM TUNNEL

----- BOUNDARY OF KUALAPUU AQUIFER SYSTEM (STATE OF HAWAII, 1990)

(770)

MAJOR ROAD AND NUMBER

$4-0800-01$

WELL AND NUMBER

Figure 1. Geographic features, island of Molokai, Hawaii, and locations of the Kualapuu area and the Kualapuu deep monitor well (4-0800-01). 


\section{Regional Setting}

The Kualapuu deep monitor well is located on the western flank of the East Molokai Volcano (fig. 2). The surface rocks near the well were mapped as the lower member of the East Molokai Volcanics (Stearns and Macdonald, 1947; Langenheim and Clague, 1987). The lower member of the East Molokai Volcanics consists of shield-stage tholeiitic, olivine-tholeiitic, and picritictholeiitic basalts, and postshield-stage alkalic basalt, and forms the bulk of East Molokai Volcano. Estimated ages of rocks of the lower member range from 1.47 million years (McDougall, 1964) to $2.00 \pm 0.86$ million years (Naughton and others, 1980). In general, the upper member consists of postshield-stage mugearite, with lesser amounts of hawaiite and trachyte, and forms a relatively thin veneer, about 50 to $500 \mathrm{ft}$ thick, over the lower member (Stearns and Macdonald, 1947). Estimated ages of rocks of the upper member are from 1.31 to 1.46 million years (McDougall, 1964).

Numerous vent features, including cinder and spatter cones, exist along the western and southern flanks of the East Molokai Volcano. Many of the vents, including the cinder cone Puu Luahine, do not appear to lie along the trends of the two primary rift zones of the volcano (fig. 2). The summit of Puu Luahine is about 3,000 ft south-southwest of the Kualapuu deep monitor well. The presence of vents in the Kualapuu area may indicate that low permeability intrusive rocks exist near the well.

In the southwestern part of the Kualapuu area, where the Kualapuu deep monitor well was drilled, a freshwater body overlies a brackish-water transition zone, which in turn overlies saltwater. Several production wells (fig. 1) northwest of the Kualapuu deep monitor well develop water from the freshwater part of the system. Measured water levels from these wells generally have ranged from about 8 to $12 \mathrm{ft}$ above sea level (Oki, 2000).

\section{Location}

The Kualapuu deep monitor well is located in the central part of Molokai on land owned by DHHL and currently (2001) leased by the Molokai Homestead Livestock Association for grazing purposes. The well was drilled north of Kahuaawi Gulch at an elevation of about $982 \mathrm{ft}$ (table 1). The well is about $2.1 \mathrm{mi}$ southeast of the intersection of highways 470 and 480 near the town of Kualapuu. Using the State of Hawaii wellnumbering system, CWRM assigned the number 4-0800-01 to the Kualapuu deep monitor well.

\section{Acknowledgments}

The Kualapuu deep monitor well was funded through a cooperative agreement between DHHL, DWS, and the USGS. The USGS acknowledges DHHL for permission to drill on their land and the Molokai Homestead Livestock Association for allowing access to the drill site. The efforts of Carolyn Darr of DHHL were instrumental in securing permission to drill on DHHL land. George Maioho and Kimo Puailihau of DHHL were extremely helpful in dealing with site selection and logistical problems associated with the drilling operation. The USGS also is grateful to the State Department of Agriculture for providing access to water needed for drilling. The State Department of Land and Natural Resources and the Maui County Department of Public Works assisted in moving the drill rig to and from the site. Kimo Akina of the U.S. Geological Survey provided drilling information. John Ocampo and Elroy Mollena of DHHL provided support for the collection of the water-conductivity and -temperature profiles from the deep monitor well.

\section{DRILLING AND WELL CONSTRUCTION}

The well was drilled by the air-rotary drilling method, in which compressed air and foam were injected down through the hollow drill stem and returned to the surface in the annular space between the drill stem and borehole wall to remove rock cuttings and water from the well. A summary of events and progress related to the well construction is provided in table 2 .

The well was drilled to a depth of $700 \mathrm{ft}$ with a 10 5/8-in. tricone bit. The well was then opened to a larger diameter with a 17-1/2-in. bit to a depth of $250 \mathrm{ft}$ prior to setting $250 \mathrm{ft}$ of nominal 12-in. solid (unperforated) steel casing. The remainder of the well, from depths of 700 to $1,585 \mathrm{ft}$, was drilled with a 9-7/8-in. tricone bit. The well is cased with 1,530 ft of 4-in. steel casing, the bottom $600 \mathrm{ft}$ of which is perforated. 


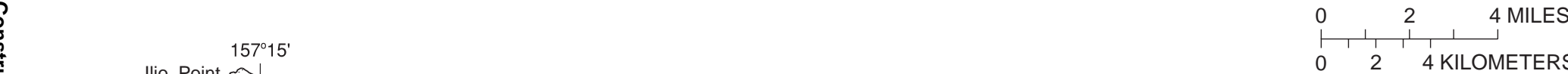

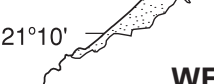

" ", hOOLEHUA

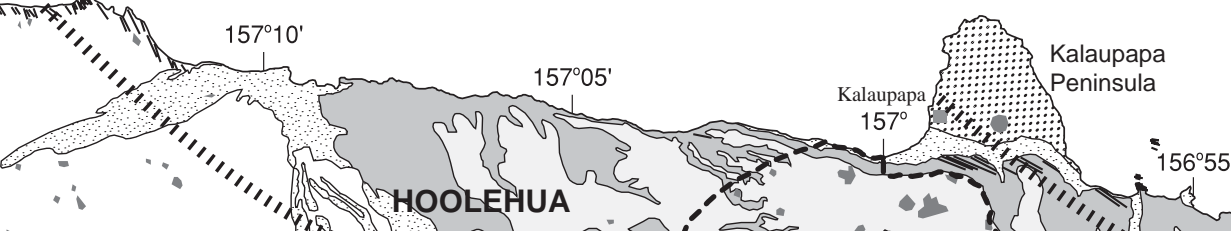

CANQ́n $1,430 \mathrm{ft}$

SLAIN
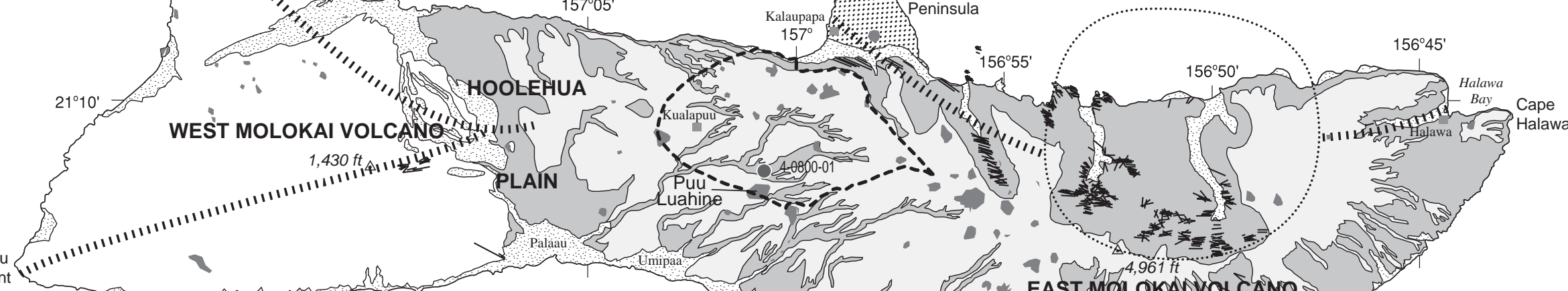

Base modified from U.S. Geological Survey digital data,
$1: 24,000,1983$, Albers equal area projection, standard
parallels $21^{\circ} 04^{\prime} 50^{\prime \prime}$ and $21^{\circ} 12^{\prime} 10^{\prime \prime}$, central meridian
$157^{\circ} 00^{\prime} 45^{\prime \prime}$

Base modified from U.S. Geological Survey digital data,
$1: 24,000,1983$, Albers equal area projection, standard
parallels $21^{\circ} 044^{\prime} 50$ and $21^{\circ} 12^{\prime} 10^{\prime \prime}$, central meridian
$157^{\circ} 00^{\prime} 45^{\prime \prime}$
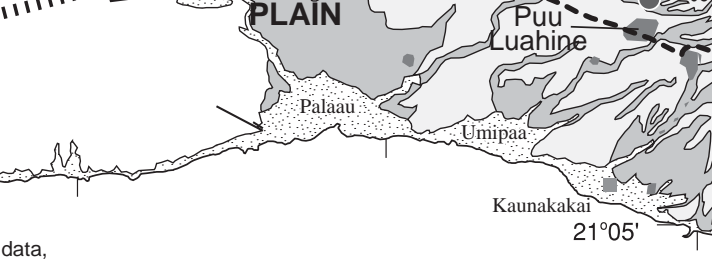

\section{EXPLANATION}

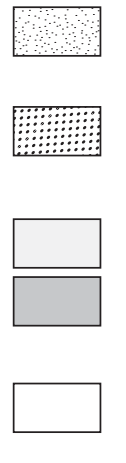

SEDIMENTARY DEPOSITS (Holocene and Pleistocene)

\section{EAST MOLOKAI VOLCANO}

Kalaupapa Volcanics (Pleistocene)

East Molokai Volcanics (Pleistocene and Pliocene)

Upper member

\section{Lower member}

WEST MOLOKAI VOLCANO

West Molokai Volcanics (Pleistocene and Pliocene)

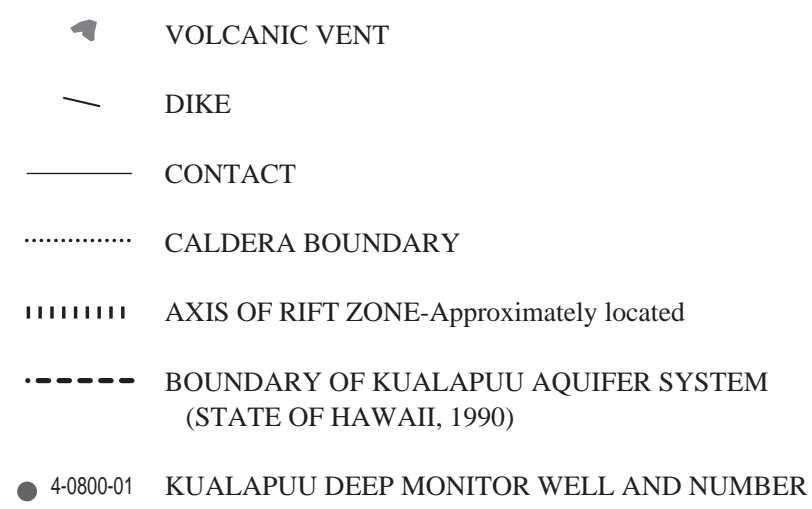

Figure 2. Generalized surficial geology of Molokai, Hawaii (from Stearns and Macdonald, 1947; and Langenheim and Clague, 1987). 
Table 1. Location, elevation, and State number of the Kualapuu deep monitor well, Molokai, Hawaii [Elevation datum is mean sea level]

$\begin{array}{ll}\text { Latitude } & 21^{\circ} 08^{\prime} 25^{\prime \prime} \text { (NAD27 datum) } \\ \text { Longitude } & 157^{\circ} 00^{\prime} 44^{\prime \prime} \text { (NAD27 datum) } \\ \text { Ground elevation at brass plate in concrete pad } & 981.90 \mathrm{feet} \\ \text { Measuring-point elevation at top of 4-inch steel casing } & 982.59 \mathrm{feet} \\ \text { Distance and direction from Kualapuu } & 2.1 \text { miles southeast } \\ \text { Distance and direction from nearest shoreline } & 3 \text { miles south } \\ \text { State well number } & 4-0800-01\end{array}$

Table 2. Summary of construction of the Kualapuu deep monitor well (4-0800-01), Molokai, Hawaii

\begin{tabular}{|c|c|}
\hline Date & Significant events \\
\hline February 3,2000 & $\begin{array}{l}\text { Started drilling with 17-1/2-in. bit to a depth of } 8 \mathrm{ft} \text {. Set temporary casing, and then } \\
\text { began drilling with 10-5/8-in. tricone bit to a depth of } 25 \mathrm{ft} \text {. }\end{array}$ \\
\hline February 4 to March 13,2000 & Drilled from depths of 25 to $505 \mathrm{ft}$ using 10-5/8-in. tricone bit. \\
\hline March 14, 2000 & $\begin{array}{l}\text { Injected air to lift rocks that had accumulated at the bottom of the well since previous } \\
\text { day from a cave-in. Drilled from depths of } 505 \text { to } 525 \mathrm{ft} \text { using } 10-5 / 8 \text {-in. tricone bit. }\end{array}$ \\
\hline March 15 to 31,2000 & $\begin{array}{l}\text { Drilled from depths of } 525 \text { to } 700 \mathrm{ft} \text { using } 10-5 / 8 \text {-in. tricone bit. Difficult to keep bot- } \\
\text { tom of well open because of caving. As much as } 80 \mathrm{ft} \text { of rocks accumulated at the } \\
\text { bottom of the well from the end of one workday to the beginning of the next. Used } \\
\text { significant amount of foam to lift rocks off bottom of well. }\end{array}$ \\
\hline April 4 to May 29, 2000 & Opened well to a larger diameter using 17-1/2-in. bit for 12-in. casing. \\
\hline May 31, 2000 & Set $250 \mathrm{ft}$ of 12 -in. solid (unperforated) steel casing. \\
\hline June 6, 2000 & $\begin{array}{l}\text { Poured } 6 \text { cubic yards of grout in annular space between 17-1/2-in. borehole and 12-in. } \\
\text { steel casing. }\end{array}$ \\
\hline June 13,2000 & Began drilling with 9-7/8-in. tricone bit. Drilled from depths of 700 to $720 \mathrm{ft}$. \\
\hline June 14 to 29,2000 & $\begin{array}{l}\text { Drilled from depths of } 720 \text { to } 845 \mathrm{ft} \text {. Difficult to keep bottom of well open because of } \\
\text { caving. As much as } 100 \mathrm{ft} \text { of rocks accumulated at the bottom of the well from the } \\
\text { end of one workday to the beginning of the next. Used significant amount of foam to } \\
\text { lift rocks off bottom of well. }\end{array}$ \\
\hline July 3,2000 & Filled bottom of well with grout up to a depth of $460 \mathrm{ft}$ to stabilize caving zones. \\
\hline July 5, 2000 & Started drilling through the grout at a depth of $460 \mathrm{ft}$. \\
\hline July 7,2000 & Drilled through the grout to a depth of about $840 \mathrm{ft}$. \\
\hline July 17 to September 19,2000 & $\begin{array}{l}\text { Drilled from depths of } 840 \text { to } 1,305 \mathrm{ft} \text {. Difficult to keep bottom of well open because of } \\
\text { caving. As much as } 110 \mathrm{ft} \text { of rocks accumulated at the bottom of the well from the } \\
\text { end of one workday to the beginning of the next. Used significant amount of foam to } \\
\text { lift rocks off bottom of well. }\end{array}$ \\
\hline September 28 to 29,2000 & $\begin{array}{l}\text { Hired a drilling company to lower a video camera down the well to inspect borehole } \\
\text { conditions. }\end{array}$ \\
\hline October 2 to 6,2000 & Cleaned out bottom of well. \\
\hline October 10, 2000 to January 16, 2001 & $\begin{array}{l}\text { Drilled from depths of } 1,305 \text { to } 1,585 \mathrm{ft} \text {. Difficult to keep bottom of well open because } \\
\text { of caving. As much as } 140 \mathrm{ft} \text { of rocks accumulated at the bottom of the well from the } \\
\text { end of one workday to the beginning of the next. Used significant amount of foam to } \\
\text { lift rocks off bottom of well. }\end{array}$ \\
\hline January 17 to 19,2001 & Cleaned out bottom of well. \\
\hline January 22 to 23,2001 & Set $1,530 \mathrm{ft}$ of 4 -in. steel casing, bottom $600 \mathrm{ft}$ perforated \\
\hline January 24, 2001 & $\begin{array}{l}\text { Poured } 3 \text { cubic yards of grout in annular space, between 12-in. and 4-in. casings, to a } \\
\text { depth of } 110 \mathrm{ft} \text {. }\end{array}$ \\
\hline
\end{tabular}


Drilling below a depth of about $500 \mathrm{ft}$ was hindered by severe caving conditions. From the end of one workday to the beginning of the next, as much as $140 \mathrm{ft}$ of rock accumulated at the bottom of the well because of caving. Large volumes of foam, as much as 55 gallons per day, were used to help lift the rocks off the bottom of the well during drilling. Although the well was drilled to a depth of $1,585 \mathrm{ft}$, about $55 \mathrm{ft}$ of rocks had accumulated at the bottom of the well between January 19 and 23, 2001, before the 4-in. steel casing could be set in place on January 23, 2001. As a result, the final depth of the well was reported by the driller to be 1,530 ft.

A concrete pad, about $4 \mathrm{ft}$ wide and $4 \mathrm{ft}$ long, was poured around the well. The elevation of a brass plate set in the southwest corner of the concrete pad is 981.90 $\mathrm{ft}$, and the elevation of the top of the 4-in steel casing is $982.59 \mathrm{ft}$. (All elevations in this report are referenced to a mean sea level datum.) Construction details of the finished well are shown in figure 3.

\section{GEOLOGIC LOG}

The geologic log (table 3, at end of report) of the Kualapuu deep monitor well was compiled by examination of rock cuttings lifted to the ground surface by the force of the compressed air and foam injected through the hollow drill stem. Although samples were collected every $5 \mathrm{ft}$, the actual depth from which the samples originated is not well known. Many of the cutting samples contain a mixture of several volcanic-rock morphologies, such as both round vesicles and angular vesicles.

The Kualapuu deep monitor well penetrated a 1,585 -ft section of soil and volcanic rock. The uppermost $80 \mathrm{ft}$ of this section consists of soil and highly weathered rock. Below the upper $80 \mathrm{ft}$ of section, rock cuttings consist of volcanic rocks with different texture, pore sizes and shapes, color, and mass, likely representing a sequence of numerous lava flows interbedded with zones of scoria.

\section{WATER-LEVEL INFORMATION}

The initial water level measured after completion of the well was $9.05 \mathrm{ft}$ above mean sea level on February 1,2001. Available water-level measurements for the Kualapuu deep monitor well during the period from
February 1 to July 13, 2001 range from 8.68 to $9.05 \mathrm{ft}$ above mean sea level (table 4). Between February 1 and July 13, 2001, the measured water level declined by $0.37 \mathrm{ft}$.

Table 4. Water-level measurements made during the period from February 1 to July 13, 2001, Kualapuu deep monitor well (4-0800-01), Molokai, Hawaii

\begin{tabular}{lc}
\hline \multicolumn{1}{c}{ Date } & $\begin{array}{c}\text { Water level, } \\
\text { in feet above mean sea level }\end{array}$ \\
\hline February 1, 2001 & 9.05 \\
April 3, 2001 & 8.87 \\
April 23, 2001 & 8.85 \\
July 13, 2001 & 8.68 \\
\hline
\end{tabular}

\section{WATER-CONDUCTIVITY AND WATER- TEMPERATURE PROFILES}

An Ocean Sensors, Incorporated Model OS200 CTD tool was first lowered down the well on April 3, 2001 (about 2 months after drilling was completed) to measure conductivity and temperature of water in the well with depth. (CTD is an acronym for conductivity, temperature, and depth.) The CTD tool was lowered down the well a second time on July 13, 2001. On both occasions, the CTD was programmed to measure conductivity, temperature, and pressure at one-second intervals and was lowered at a rate of about 15-20 feet per minute using a stainless steel cable marked at 100-ft intervals. Water conductivity is an indicator of water salinity, with higher conductivity indicating higher salinity. The OS200 CTD measures water conductivity at the prevailing water temperature, and does not adjust the conductivity to a reference temperature (such as 25 ${ }^{\circ} \mathrm{C}$ ), which would provide a measure of specific conductance. Measurement depths were computed from the pressure, conductivity, and temperature data. Depths were adjusted using a linear correction equation derived by comparing estimated depths from the pressure, conductivity, and temperature data with known depths (from the marked cable) at which the CTD was held during logging on April 3, 2001. The same correction equation was applied to adjust the estimated depths from the July 13, 2001 profile.

Conductivity profile, April 3, 2001.-Conductivity of water in the well was lowest and nearly uniform (about 600 to 700 microsiemens/cm) from the water table down to a depth of about $275 \mathrm{ft}$ below sea level (fig. 4). Below this upper zone, water conductivity 


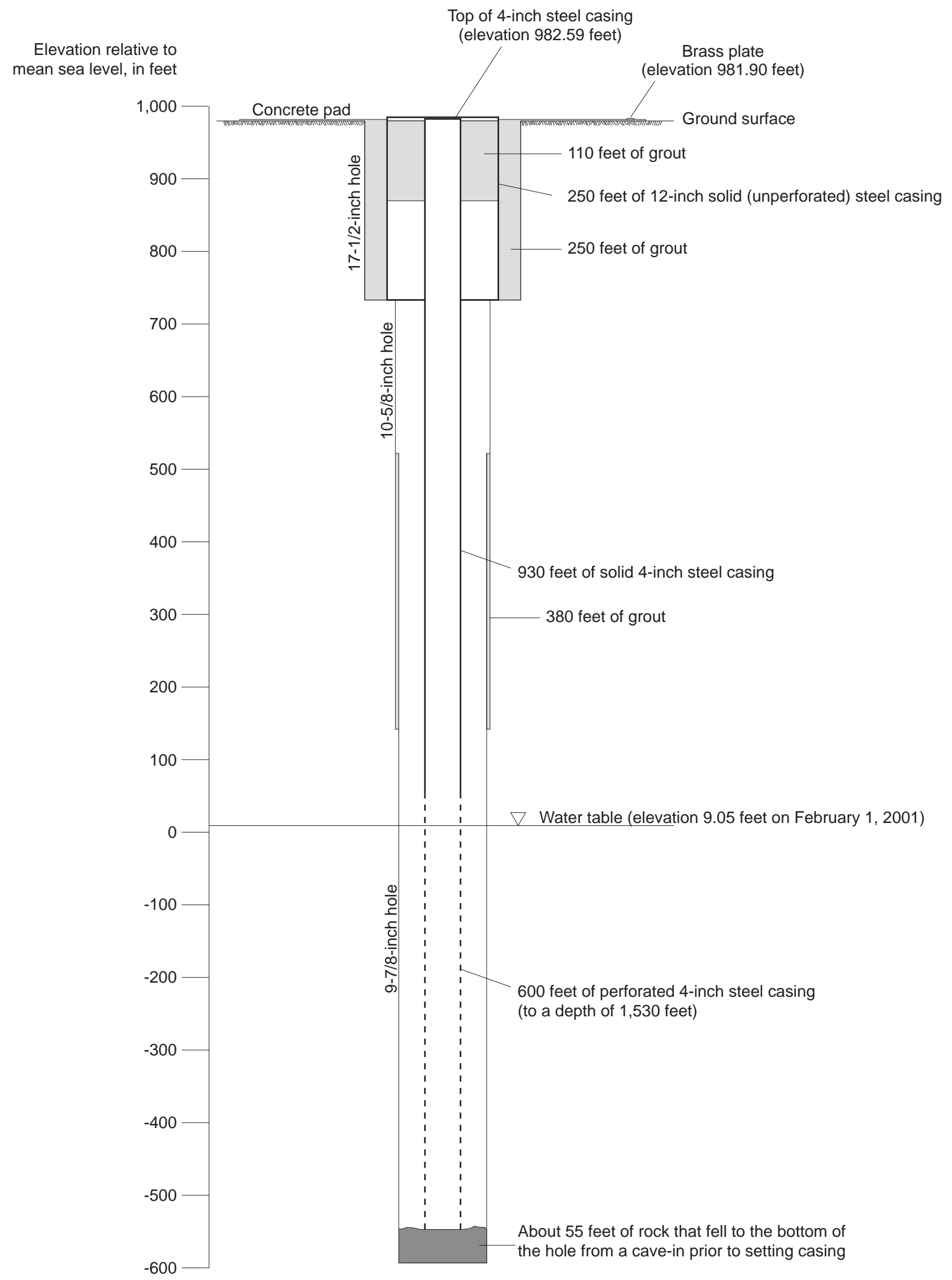

Figure 3. Construction details for the Kualapuu deep monitor well (4-0800-01), Molokai, Hawaii. 

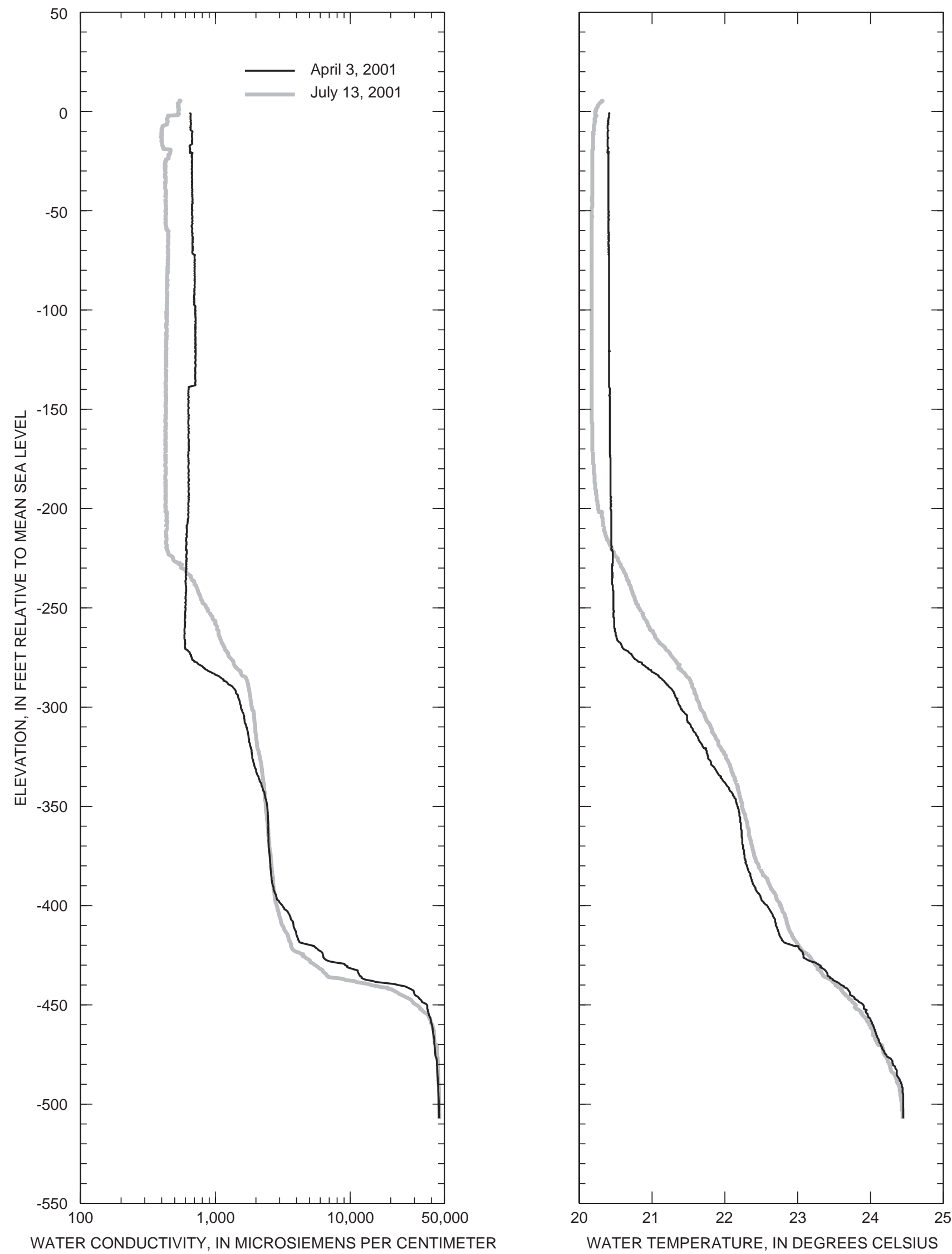

Figure 4. Water-conductivity and -temperature profiles measured in the Kualapuu deep monitor well (4-0800-01) on April 3 and July 13, 2001, Molokai, Hawaii. Data available from the USGS Hawaii District log archive. 
increased with depth in the well. Water conductivity increased gradually from about 700 microsiemens $/ \mathrm{cm}$ at a depth of $275 \mathrm{ft}$ below sea level to about 3,000 microsiemens/cm at a depth of $400 \mathrm{ft}$ below sea level. The average change of conductivity with depth in the lower part of the profile (from $400 \mathrm{ft}$ below sea level to $507 \mathrm{ft}$ below sea level, which represents the bottom of the measured profile) was greater than the average change measured higher in the profile (from the water table to $400 \mathrm{ft}$ below sea level). At a depth of about 440 feet below sea level, the conductivity of water in the well was about 25,000 microsiemens/cm, and near the bottom of the measured profile the conductivity was about 46,000 microsiemens $/ \mathrm{cm}$.

For comparison, water pumped in 1997 from DHHL wells 1 (4-0801-01) and 2 (4-0801-02) in the Kualapuu area had specific-conductance values of about 300 to 400 microsiemens $/ \mathrm{cm}$. The corresponding chloride concentrations of pumped water ranged from about 60 to $120 \mathrm{mg} / \mathrm{L}$ (Hill and others, 1998).

Conductivity profile, July 13, 2001.-Conductivity of water in the well was lowest and nearly uniform (about 400 to 550 microsiemens $/ \mathrm{cm}$ ) from the water table down to a depth of about $220 \mathrm{ft}$ below sea level (fig. 4). Below this upper zone, conductivity of water increased with depth in the well. Water conductivity increased gradually from about 450 microsiemens $/ \mathrm{cm}$ at a depth of $220 \mathrm{ft}$ below sea level to about 3,000 microsiemens $/ \mathrm{cm}$ at a depth of $400 \mathrm{ft}$ below sea level. The average change of conductivity with depth in the lower part of the profile (from $400 \mathrm{ft}$ below sea level to $507 \mathrm{ft}$ below sea level, which represents the bottom of the measured profile) was greater than the average change measured higher in the profile (from the water table to $400 \mathrm{ft}$ below sea level). At a depth of about 445 feet below sea level, the conductivity of water in the well was about 25,000 microsiemens/cm, and near the bottom of the measured profile the conductivity was about 46,000 microsiemens/cm.

Temperature profile, April 3, 2001.- The temperature of water in the well was coolest near the water table and warmest near the bottom of the measured profile (fig. 4). From the water table to a depth of about 260 $\mathrm{ft}$ below sea level, water temperature was nearly uniform, ranging from 20.4 to $20.5^{\circ} \mathrm{C}$. From $260 \mathrm{ft}$ below sea level to the bottom of the measured profile, the water temperature increased from 20.5 to $24.5^{\circ} \mathrm{C}$.
Temperature profile, July 13, 2001.-The temperature of water in the well was coolest near the water table and warmest near the bottom of the measured profile (fig. 4). From the water table to a depth of about 200 $\mathrm{ft}$ below sea level, water temperature was nearly uniform, ranging from 20.2 to $20.3^{\circ} \mathrm{C}$. From $200 \mathrm{ft}$ below sea level to the bottom of the measured profile, the water temperature increased from 20.3 to $24.5^{\circ} \mathrm{C}$.

Comparison of measured profiles.-In general, water-conductivity and -temperature profiles indicate that an upper zone of nearly uniform water quality exists in the well, and this zone contains water with the lowest salinity and temperature relative to water lower in the well. However, between April 3 and July 13, 2001, the thickness of this zone decreased by about 50 to $60 \mathrm{ft}$. Aspects of the water-conductivity and -temperature profiles measured on April 3, 2001 differ from the water-conductivity and -temperature profiles, respectively, measured on July 13, 2001. A comparison of changes in water conductivity and temperature from April 3 to July 13, 2001 at common depths indicates that (1) cooler, lower-salinity water entered the upper part of the well, from the water table down to a depth of about $220 \mathrm{ft}$ below sea level, (2) warmer water entered the well between depths of 220 to $420 \mathrm{ft}$ below sea level, (3) higher-salinity water entered the well between depths of 230 to $340 \mathrm{ft}$ below sea level, and (4) lowersalinity water entered the well between depths of 400 to $450 \mathrm{ft}$ below sea level.

Continued monitoring of water quality in the well with time will provide the information necessary to evaluate whether the changes in water conductivity and temperature are related to (1) natural replacement of water that was lifted up the well during drilling, (2) vertical flow of water in the well caused by a vertical hydraulic-head gradient in the aquifer, (3) regional effects of time-varying ground-water recharge and withdrawal rates, or (4) other factors.

\section{SUMMARY AND CONCLUSIONS}

During February 2000 to January 2001, a monitor well was drilled in the Kualapuu area of central Molokai, Hawaii by the U.S. Geological Survey in cooperation with the State Department of Hawaiian Home Lands and the Maui County Department of Water Supply. The well is located at a ground-surface elevation of about $982 \mathrm{ft}$, near the area that supplies much of the 
drinking water on Molokai, and was designed to provide information necessary to effectively manage the ground-water resources in the area.

Measured water levels from the Kualapuu deep monitor well declined from 9.05 to $8.68 \mathrm{ft}$ above mean sea level from February 1 to July 13, 2001. Water conductivity in the well generally is lowest (less than 700 microsiemens $/ \mathrm{cm}$ ) near the water table and highest (about 46,000 microsiemens $/ \mathrm{cm}$ ) near the bottom of the measured profiles that were collected on April 3 and July 13, 2001. Water temperatures in the well are generally lowest (less than $20.5^{\circ} \mathrm{C}$ ) near the water table and highest (about $24.5^{\circ} \mathrm{C}$ ) near the bottom of the measured profiles. Water-conductivity and -temperature profiles indicate that an upper zone of nearly uniform water quality exists in the well, and this zone contains water with the lowest salinity and temperature relative to water lower in the well. However, between April 3 and July 13,2001 , the thickness of this zone decreased by about 50 to $60 \mathrm{ft}$.

\section{REFERENCES CITED}

Hill, B.R., Taogoshi, R.I., Kunishige, V.E., and Shibata, W.S., 1998, Water resources data Hawaii, water year 1997: U.S. Geological Survey Water-Data Report HI-97$1,507 \mathrm{p}$.

Langenheim, V.A.M., and Clague, D.A., 1987, The Hawaiian-Emperor volcanic chain, part II, stratigraphic framework of volcanic rocks of the Hawaiian Islands, chap. 1 of Decker, R.W., Wright, T.L., and Stauffer, P.H., eds., Volcanism in Hawaii: U.S. Geological Survey Professional Paper 1350, v. 1, p. 55-84.
McDougall, Ian, 1964, Potassium-argon ages from lavas of the Hawaiian islands: Geological Society of America Bulletin, v. 75, no. 2, p. 107-128.

Naughton, J.J., Macdonald, G.A., and Greenberg, V.A., 1980, Some additional potassium-argon ages of Hawaiian rocks: The Maui Volcanic Complex of Molokai, Maui, Lanai and Kahoolawe: Journal of Volcanology and Geothermal Research, v. 7, no. 3/4, p. 339-355.

Oki, D.S., 2000, Site selection for a deep monitor well, Kualapuu, Molokai, Hawaii: U.S. Geological Survey Water-Resources Investigations Report 99-4291, 50 p.

State of Hawaii, 1990, Water Resources Protection Plan, volumes I and II, Hawaii Water Plan: State of Hawaii, Commission on Water Resource Management, variously paged.

Stearns, H.T., and Macdonald, G.A., 1947, Geology and ground-water resources of the island of Molokai, Hawaii: Hawaii Division of Hydrography Bulletin 11, Territory of Hawaii, 113 p. 
Table 3. Lithologic descriptions of rock cuttings from the Kualapuu deep monitor well (4-0800-01), Molokai, Hawaii

[Datum is mean sea level; depth measured from 982 feet above sea level; mm, millimeter; <, less than; <<, much less than; , about; samples were collected every 5 feet, but the actual depth from which the samples originated is not well known; many of the samples contain a mixture of several volcanic-rock morphologies]

\begin{tabular}{|c|c|c|c|c|c|c|}
\hline \multicolumn{3}{|c|}{$\begin{array}{l}\text { Elevation } \\
\text { (feet) }\end{array}$} & \multicolumn{3}{|c|}{$\begin{array}{l}\text { Depth } \\
\text { (feet) }\end{array}$} & \multirow[t]{2}{*}{ Sample description } \\
\hline 982 & to & 977 & 0 & to & 5 & \\
\hline 977 & to & 972 & 5 & to & 10 & Red lateritic clay and grit, highly weathered rock with small vesicles lined with manganese \\
\hline 967 & to & 962 & 15 & to & 20 & Red lateritic clay and grit, highly weathered rock with small vesicles lined with manganese \\
\hline 962 & to & 957 & 20 & to & 25 & Red lateritic clay and grit, highly weathered rock with small vesicles lined with manganese \\
\hline 957 & to & 952 & 25 & to & 30 & Red-brown highly weathered rock \\
\hline 947 & to & 942 & 35 & to & 40 & Red-brown highly weathered rock containing weathered laths of plagioclase \\
\hline 942 & to & 937 & 40 & to & 45 & Red-brown highly weathered rock containing weathered laths of plagioclase \\
\hline 937 & to & 932 & 45 & to & 50 & Red-brown highly weathered rock containing weathered laths of plagioclase \\
\hline 932 & to & 927 & 50 & to & 55 & Brown highly weathered rock more competent than previous samples \\
\hline 927 & to & 922 & 55 & to & 60 & Brown highly weathered rock containing small laths of plagioclase \\
\hline 922 & to & 917 & 60 & to & 65 & Brown highly weathered rock containing small laths of plagioclase \\
\hline 902 & to & 897 & 80 & to & 85 & Dense gray rock containing sparse phenocrysts of clear plagioclase and pyroxene \\
\hline 897 & to & 892 & 85 & to & 90 & $\begin{array}{l}\text { Dense gray rock containing sparse phenocrysts of clear plagioclase, pyroxene, and olivine; some } \\
\text { cuttings are vesicular with round and angular vesicles }\end{array}$ \\
\hline 892 & to & 887 & 90 & to & 95 & $\begin{array}{l}\text { Dense gray rock containing sparse phenocrysts of clear plagioclase, pyroxene, and olivine; some } \\
\text { cuttings are vesicular with round and angular vesicles }\end{array}$ \\
\hline 887 & to & 882 & 95 & to & 100 & $\begin{array}{l}\text { Dense gray rock containing sparse phenocrysts of clear plagioclase, pyroxene, and olivine; some } \\
\text { cuttings are vesicular with round and angular vesicles; manganese lining some of the vesicles }\end{array}$ \\
\hline 882 & to & 877 & 100 & to & 105 & $\begin{array}{l}\text { Dense gray rock containing sparse phenocrysts of clear plagioclase, pyroxene, and olivine; some } \\
\text { cuttings are vesicular with round and angular vesicles; manganese lining some of the vesicles }\end{array}$ \\
\hline 877 & to & 872 & 105 & to & 110 & $\begin{array}{l}\text { Dense gray rock containing sparse phenocrysts of clear plagioclase, pyroxene, and olivine; some } \\
\text { cuttings are coated with iron oxide }\end{array}$ \\
\hline 872 & to & 867 & 110 & to & 115 & $\begin{array}{l}\text { Dense gray rock containing sparse phenocrysts of clear plagioclase, pyroxene, and olivine; some } \\
\text { cuttings are coated with iron oxide }\end{array}$ \\
\hline 842 & to & 837 & 140 & to & 145 & Dense dark gray rock containing phenocrysts of olivine $\sim 1.0 \mathrm{~mm}$ across \\
\hline 837 & to & 832 & 145 & to & 150 & $\begin{array}{l}\text { Dense dark gray rock containing phenocrysts of olivine } \sim 1.0 \mathrm{~mm} \text { across; one plagioclase phenoc- } \\
\text { ryst } \sim 1.0 \mathrm{~mm} \text { long }\end{array}$ \\
\hline 832 & to & 827 & 150 & to & 155 & Dense dark gray rock containing phenocrysts of olivine $\sim 1.0 \mathrm{~mm}$ across \\
\hline 827 & to & 822 & 155 & to & 160 & Mixture of dense gray rock and rock with round vesicles \\
\hline 822 & to & 817 & 160 & to & 165 & Dense dark gray rock with small angular vesicles containing sparse pyroxene phenocrysts \\
\hline 817 & to & 812 & 165 & to & 170 & Dense gray rock containing sparse phenocrysts of weathered olivine and plagioclase \\
\hline 812 & to & 807 & 170 & to & 175 & Dense gray aphyric rock \\
\hline 807 & to & 802 & 175 & to & 180 & Dense gray aphyric rock \\
\hline 802 & to & 797 & 180 & to & 185 & Mixture of dense dark gray-black rock and slightly vesicular gray rock \\
\hline 797 & to & 792 & 185 & to & 190 & $\begin{array}{l}\text { Dense dark gray-black rock containing sparse weathered phenocrysts of pyroxene and olivine } \\
<1.0 \mathrm{~mm} \text { across }\end{array}$ \\
\hline 792 & to & 787 & 190 & to & 195 & Dense dark gray-black rock; some highly weathered rotted red cuttings mixed in \\
\hline 787 & to & 782 & 195 & to & 200 & Mixture of dark gray vesicular and nonvesicular rock \\
\hline 782 & to & 777 & 200 & to & 205 & Mixture of dark gray vesicular and nonvesicular rock \\
\hline 777 & to & 772 & 205 & to & 210 & Dark gray rock with angular vesicles \\
\hline 772 & to & 767 & 210 & to & 215 & Dark gray rock with angular vesicles \\
\hline
\end{tabular}


Table 3. Lithologic descriptions of rock cuttings from the Kualapuu deep monitor well (4-0800-01), Molokai, Hawaii--Continued [Datum is mean sea level; depth measured from 982 feet above sea level; mm, millimeter; <, less than; <<, much less than; , about; samples were collected every 5 feet, but the actual depth from which the samples originated is not well known; many of the samples contain a mixture of several volcanic-rock morphologies]

\begin{tabular}{|c|c|c|c|c|c|c|}
\hline \multicolumn{3}{|c|}{$\begin{array}{l}\text { Elevation } \\
\text { (feet) }\end{array}$} & \multicolumn{3}{|c|}{$\begin{array}{l}\text { Depth } \\
\text { (feet) }\end{array}$} & \multirow[t]{2}{*}{ Sample description } \\
\hline 767 & to & 762 & 215 & to & 220 & \\
\hline 762 & to & 757 & 220 & to & 225 & Dense dark gray aphyric rock; sparse phenocrysts of pyroxene \\
\hline 752 & to & 747 & 230 & to & 235 & Sand-size cuttings; gray with weathered milky white plagioclase phenocrysts \\
\hline 747 & to & 742 & 235 & to & 240 & Sand-size cuttings; gray with weathered milky white plagioclase phenocrysts \\
\hline 737 & to & 732 & 245 & to & 250 & Dark gray rock slightly vesicular with round to subround vesicles \\
\hline 732 & to & 727 & 250 & to & 255 & Dark gray rock slightly vesicular with round to subround vesicles; fewer vesicles \\
\hline 727 & to & 722 & 255 & to & 260 & Dark gray rock slightly vesicular with round to subround vesicles; fewer vesicles \\
\hline 722 & to & 717 & 260 & to & 265 & $\begin{array}{l}\text { Highly weathered clay rock; weathered crystal-lithic material; grains of olivine and abundant } \\
\text { plagioclase }<<0.5 \mathrm{~mm} \text { across }\end{array}$ \\
\hline 717 & to & 712 & 265 & to & 270 & $\begin{array}{l}\text { Highly weathered clay rock; weathered crystal-lithic material; grains of olivine and abundant } \\
\text { plagioclase }<<0.5 \mathrm{~mm} \text { across }\end{array}$ \\
\hline 702 & to & 697 & 280 & to & 285 & Dense dark gray rock \\
\hline 697 & to & 692 & 285 & to & 290 & Dense dark gray rock containing microphenocrysts of olivine and weathered plagioclase \\
\hline 692 & to & 687 & 290 & to & 295 & Dense dark gray rock containing microphenocrysts of olivine and weathered plagioclase \\
\hline 687 & to & 682 & 295 & to & 300 & Weathered light gray massive rock \\
\hline 682 & to & 677 & 300 & to & 305 & Dense red-brown rock (sample wet) \\
\hline 677 & to & 672 & 305 & to & 310 & $\begin{array}{l}\text { Dense red-brown rock; sample contains sparse phenocrysts of olivine } \sim 0.5 \mathrm{~mm} \text { across (sample } \\
\text { wet) }\end{array}$ \\
\hline 672 & to & 667 & 310 & to & 315 & Dark gray vesicular rock with angular to subangular vesicles (sample wet) \\
\hline 667 & to & 662 & 315 & to & 320 & Brown-gray vesicular rock with angular to subangular vesicles; sparse olivine microphenocrysts \\
\hline 662 & to & 657 & 320 & to & 325 & $\begin{array}{l}\text { Brown-gray vesicular rock with angular to subangular vesicles; sparse plagioclase and olivine } \\
\text { microphenocrysts }\end{array}$ \\
\hline 652 & to & 647 & 330 & to & 335 & $\begin{array}{l}\text { Mixture of dark gray vesicular and gray nonvesicular rock with iron oxide lining surfaces, minor } \\
\text { amount of tachylyte cuttings }\end{array}$ \\
\hline 647 & to & 642 & 335 & to & 340 & $\begin{array}{l}\text { Mixture of dark gray vesicular and gray nonvesicular rock with iron oxide lining surfaces, minor } \\
\text { amount of tachylyte cuttings and red rock }\end{array}$ \\
\hline 642 & to & 637 & 340 & to & 345 & Dense dark gray rock containing abundant microphenocrysts of olivine and glassy plagioclase \\
\hline 637 & to & 632 & 345 & to & 350 & Dense dark gray rock containing abundant microphenocrysts of olivine and glassy plagioclase \\
\hline 632 & to & 627 & 350 & to & 355 & Dense dark gray rock containing abundant microphenocrysts of olivine and glassy plagioclase \\
\hline 627 & to & 622 & 355 & to & 360 & $\begin{array}{l}\text { Dense dark gray rock containing abundant microphenocrysts of olivine, glassy plagioclase, and } \\
\text { pyroxene }\end{array}$ \\
\hline 622 & to & 617 & 360 & to & 365 & $\begin{array}{l}\text { Dense dark gray rock containing abundant microphenocrysts of olivine, glassy plagioclase, and } \\
\text { pyroxene }\end{array}$ \\
\hline 617 & to & 612 & 365 & to & 370 & $\begin{array}{l}\text { Dense dark gray rock containing abundant microphenocrysts of olivine, glassy plagioclase, and } \\
\text { pyroxene; iron oxide coats surfaces of the rock; one plagioclase lath } 1.5 \mathrm{~mm} \text { long }\end{array}$ \\
\hline 612 & to & 607 & 370 & to & 375 & Gray vesicular rock with angular vesicles \\
\hline 607 & to & 602 & 375 & to & 380 & Dense gray rock with small angular vesicles \\
\hline 602 & to & 597 & 380 & to & 385 & Dense gray rock with angular vesicles \\
\hline 597 & to & 592 & 385 & to & 390 & Dense gray rock with angular vesicles; one weathered plagioclase phenocryst $<1.0 \mathrm{~mm}$ long \\
\hline 592 & to & 587 & 390 & to & 395 & Dense gray rock with angular vesicles and microphenocrysts of plagioclase $<<0.5 \mathrm{~mm}$ across \\
\hline 587 & to & 582 & 395 & to & 400 & Dense gray rock with angular vesicles and microphenocrysts of plagioclase $<<0.5 \mathrm{~mm}$ across \\
\hline 582 & to & 577 & 400 & to & 405 & $\begin{array}{l}\text { Brown slightly vesicular rock containing sparse phenocrysts of plagioclase } 1.0 \mathrm{~mm} \text { long; some } \\
\text { cuttings have rounded vesicles }\end{array}$ \\
\hline 577 & to & 572 & 405 & to & 410 & Dense gray aphyric rock \\
\hline 572 & to & 567 & 410 & to & 415 & Mixture of dense gray slightly vesicular aphyric rock and vesicular gray rock with round vesicles \\
\hline
\end{tabular}


Table 3. Lithologic descriptions of rock cuttings from the Kualapuu deep monitor well (4-0800-01), Molokai, Hawaii--Continued [Datum is mean sea level; depth measured from 982 feet above sea level; mm, millimeter; <, less than; <<, much less than; , about; samples were collected every 5 feet, but the actual depth from which the samples originated is not well known; many of the samples contain a mixture of several volcanic-rock morphologies]

\begin{tabular}{|c|c|c|c|c|c|c|}
\hline \multicolumn{3}{|c|}{$\begin{array}{l}\text { Elevation } \\
\text { (feet) }\end{array}$} & \multicolumn{3}{|c|}{$\begin{array}{l}\text { Depth } \\
\text { (feet) }\end{array}$} & \multirow{2}{*}{$\begin{array}{l}\text { Sample description } \\
\text { Mixture of dense gray slightly vesicular aphyric rock and vesicular gray rock with round vesicles }\end{array}$} \\
\hline 567 & to & 562 & 415 & to & 420 & \\
\hline 562 & to & 557 & 420 & to & 425 & Mixture of dense gray slightly vesicular aphyric rock and vesicular gray rock with round vesicles \\
\hline 552 & to & 547 & 430 & to & 435 & $\begin{array}{l}\text { Mixture of red scoriaceous rock and dense dark gray vesicular rock with angular vesicles and } \\
\text { plagioclase phenocrysts } 1.0 \mathrm{~mm} \text { long }\end{array}$ \\
\hline 542 & to & 537 & 440 & to & 445 & $\begin{array}{l}\text { Dense brown-gray rock with angular vesicles containing plagioclase phenocrysts } 1.0-2.0 \mathrm{~mm} \\
\text { long }\end{array}$ \\
\hline 537 & to & 532 & 445 & to & 450 & $\begin{array}{l}\text { Mixture of brown vesicular rock with angular vesicles and dense nonvesicular rock containing } \\
\text { sparse phenocrysts of plagioclase }\end{array}$ \\
\hline 532 & to & 527 & 450 & to & 455 & Highly vesicular rock with angular vesicles and sparse plagioclase phenocrysts \\
\hline 527 & to & 522 & 455 & to & 460 & Dense dark brown rock with angular vesicles and microphenocrysts of plagioclase \\
\hline 512 & to & 507 & 470 & to & 475 & Dense dark gray aphyric rock \\
\hline 507 & to & 502 & 475 & to & 480 & Dark gray vesicular rock with angular vesicles; sparse phenocrysts of plagioclase $<1.0 \mathrm{~mm}$ long \\
\hline 502 & to & 497 & 480 & to & 485 & Dark gray vesicular rock with angular vesicles; sparse phenocrysts of plagioclase $<1.0 \mathrm{~mm}$ long \\
\hline 497 & to & 492 & 485 & to & 490 & $\begin{array}{l}\text { Dark gray vesicular rock with angular vesicles; sparse phenocrysts of plagioclase and olivine } \\
<1.0 \mathrm{~mm} \text { long }\end{array}$ \\
\hline 492 & to & 487 & 490 & to & 495 & $\begin{array}{l}\text { Dark gray vesicular rock with angular vesicles; phenocrysts of plagioclase }<1.0 \mathrm{~mm} \text { long repre- } \\
\text { senting about } 5 \text { percent of sample }\end{array}$ \\
\hline 487 & to & 482 & 495 & to & 500 & Dark gray vesicular rock with angular vesicles; sparse phenocrysts of plagioclase and olivine \\
\hline 482 & to & 477 & 500 & to & 505 & Dark gray vesicular rock with angular vesicles; sparse phenocrysts of plagioclase and olivine \\
\hline 477 & to & 472 & 505 & to & 510 & $\begin{array}{l}\text { Mixture of brown-gray vesicular and nonvesicular rock; sparse plagioclase phenocrysts }<1.0 \mathrm{~mm} \\
\text { long }\end{array}$ \\
\hline 472 & to & 467 & 510 & to & 515 & Gray-brown vesicular rock with angular vesicles \\
\hline 467 & to & 462 & 515 & to & 520 & Gray-brown vesicular rock with angular vesicles; sparse phenocrysts of plagioclase and olivine \\
\hline 462 & to & 457 & 520 & to & 525 & Dense gray-brown aphyric rock \\
\hline 457 & to & 452 & 525 & to & 530 & Vesicular gray-brown aphyric rock with angular vesicles \\
\hline 452 & to & 447 & 530 & to & 535 & Vesicular gray-brown aphyric rock with angular vesicles \\
\hline 447 & to & 442 & 535 & to & 540 & Slightly vesicular dark gray rock with small angular vesicles \\
\hline 442 & to & 437 & 540 & to & 545 & Slightly vesicular dark gray rock with small angular vesicles \\
\hline 437 & to & 432 & 545 & to & 550 & $\begin{array}{l}\text { Mixture of dense gray nonvesicular aphyric rock and vesicular gray aphyric rock with angular } \\
\text { vesicles }\end{array}$ \\
\hline 432 & to & 427 & 550 & to & 555 & Vesicular gray aphyric rock with angular vesicles \\
\hline 427 & to & 422 & 555 & to & 560 & Dense gray rock with angular vesicles; sparse phenocrysts of plagioclase \\
\hline 422 & to & 417 & 560 & to & 565 & $\begin{array}{l}\text { Mixture of dense gray nonvesicular aphyric rock and vesicular gray aphyric rock with angular } \\
\text { vesicles }\end{array}$ \\
\hline 417 & to & 412 & 565 & to & 570 & Dense dark gray rock; sparse phenocrysts of plagioclase \\
\hline 412 & to & 407 & 570 & to & 575 & Dense gray nonvesicular rock; sparse phenocrysts of plagioclase \\
\hline 407 & to & 402 & 575 & to & 580 & Dense gray vesicular rock with angular vesicles; sparse phenocrysts of plagioclase \\
\hline 402 & to & 397 & 580 & to & 585 & Red-brown vesicular aphyric rock (clinker) \\
\hline 397 & to & 392 & 585 & to & 590 & $\begin{array}{l}\text { Red-brown vesicular aphyric rock (clinker); sparse phenocrysts of olivine and plagioclase up to } 3 \\
\text { mm across }\end{array}$ \\
\hline 392 & to & 387 & 590 & to & 595 & $\begin{array}{l}\text { Red-gray scoriaceous rock with elongated vesicles; phenocrysts of plagioclase and olivine } \sim 1.0 \\
\text { mm across }\end{array}$ \\
\hline 387 & to & 382 & 595 & to & 600 & $\begin{array}{l}\text { Red-gray scoriaceous rock with elongated and angular vesicles; phenocrysts of plagioclase and } \\
\text { olivine } \sim 1.0 \mathrm{~mm} \text { across }\end{array}$ \\
\hline 382 & to & 377 & 600 & to & 605 & $\begin{array}{l}\text { Mixture of dense gray vesicular aphyric rock with angular vesicles and gray rock with round ves- } \\
\text { icles }\end{array}$ \\
\hline 377 & to & 372 & 605 & to & 610 & Dense gray aphyric rock with some angular vesicles \\
\hline
\end{tabular}


Table 3. Lithologic descriptions of rock cuttings from the Kualapuu deep monitor well (4-0800-01), Molokai, Hawaii--Continued [Datum is mean sea level; depth measured from 982 feet above sea level; mm, millimeter; <, less than; <<, much less than; , about; samples were collected every 5 feet, but the actual depth from which the samples originated is not well known; many of the samples contain a mixture of several volcanic-rock morphologies]

\begin{tabular}{|c|c|c|c|c|c|c|}
\hline \multicolumn{3}{|c|}{$\begin{array}{l}\text { Elevation } \\
\text { (feet) }\end{array}$} & \multicolumn{3}{|c|}{$\begin{array}{l}\text { Depth } \\
\text { (feet) }\end{array}$} & \multirow{2}{*}{$\begin{array}{l}\text { Sample description } \\
\text { Gray vesicular rock with angular vesicles; phenocrysts of plagioclase }<1.0 \mathrm{~mm} \text { acro }\end{array}$} \\
\hline 372 & to & 367 & 610 & to & 615 & \\
\hline 367 & to & 362 & 615 & to & 620 & Gray vesicular rock with angular vesicles \\
\hline 362 & to & 357 & 620 & to & 625 & Gray vesicular rock with angular vesicles; microphenocrysts of olivine $<0.5 \mathrm{~mm}$ across \\
\hline 357 & to & 352 & 625 & to & 630 & $\begin{array}{l}\text { Gray vesicular rock with angular vesicles; microphenocrysts of olivine and plagioclase }<0.5 \mathrm{~mm} \\
\text { across }\end{array}$ \\
\hline 352 & to & 347 & 630 & to & 635 & Dense nonvesicular dark gray rock \\
\hline 347 & to & 342 & 635 & to & 640 & $\begin{array}{l}\text { Vesicular gray rock with angular vesicles; phenocrysts of olivine and minor amount of plagio- } \\
\text { clase }\end{array}$ \\
\hline 342 & to & 337 & 640 & to & 645 & Vesicular gray rock with angular vesicles \\
\hline 337 & to & 332 & 645 & to & 650 & $\begin{array}{l}\text { Mixture of dense gray nonvesicular aphyric rock and dark gray vesicular aphyric rock with angu- } \\
\text { lar vesicles }\end{array}$ \\
\hline 332 & to & 327 & 650 & to & 655 & $\begin{array}{l}\text { Mixture of dense gray nonvesicular aphyric rock and dark gray vesicular aphyric rock with angu- } \\
\text { lar vesicles }\end{array}$ \\
\hline 327 & to & 322 & 655 & to & 660 & Vesicular gray rock with angular vesicles; phenocrysts of olivine and plagioclase $1-2 \mathrm{~mm}$ across \\
\hline 322 & to & 317 & 660 & to & 665 & $\begin{array}{l}\text { Mixture of dense gray nonvesicular aphyric rock and dark gray vesicular aphyric rock with angu- } \\
\text { lar vesicles }\end{array}$ \\
\hline 317 & to & 312 & 665 & to & 670 & $\begin{array}{l}\text { Vesicular gray-brown rock with angular vesicles; sparse phenocrysts of plagioclase laths } 1.0 \mathrm{~mm} \\
\text { long }\end{array}$ \\
\hline 312 & to & 307 & 670 & to & 675 & $\begin{array}{l}\text { Vesicular gray-brown rock with angular vesicles; sparse phenocrysts of olivine and plagioclase } \\
\text { laths } 1.0 \mathrm{~mm} \text { long }\end{array}$ \\
\hline 307 & to & 302 & 675 & to & 680 & Mixture of dark gray nonvesicular aphyric rock and vesicular aphyric rock with angular vesicles \\
\hline 302 & to & 297 & 680 & to & 685 & Slightly vesicular gray-brown aphyric rock with small angular vesicles \\
\hline 297 & to & 292 & 685 & to & 690 & Gray vesicular rock with angular vesicles; phenocrysts of plagioclase 1-2.0 mm long \\
\hline 292 & to & 287 & 690 & to & 695 & Dark gray vesicular aphyric rock with angular vesicles \\
\hline 287 & to & 282 & 695 & to & 700 & Mixture of dark gray nonvesicular aphyric rock and vesicular aphyric rock with angular vesicles \\
\hline 282 & to & 277 & 700 & to & 705 & Mixture of dark gray nonvesicular aphyric rock and vesicular aphyric rock with angular vesicles \\
\hline 277 & to & 272 & 705 & to & 710 & Mixture of dark gray nonvesicular aphyric rock and vesicular aphyric rock with angular vesicles \\
\hline 272 & to & 267 & 710 & to & 715 & $\begin{array}{l}\text { Slightly vesicular gray-brown aphyric rock with small angular vesicles; cuttings coated with } \\
\text { microphenocrysts of plagioclase, olivine, and possibly pyroxene }\end{array}$ \\
\hline 267 & to & 262 & 715 & to & 720 & $\begin{array}{l}\text { Slightly vesicular gray-brown aphyric rock with small angular vesicles; cuttings coated with } \\
\text { microphenocrysts of plagioclase, olivine, and possibly pyroxene }\end{array}$ \\
\hline 262 & to & 257 & 720 & to & 725 & $\begin{array}{l}\text { Slightly vesicular gray-brown aphyric rock with small angular vesicles; cuttings coated with } \\
\text { microphenocrysts of plagioclase, olivine, and possibly pyroxene; clay present with manganese } \\
\text { staining }\end{array}$ \\
\hline 257 & to & 252 & 725 & to & 730 & $\begin{array}{l}\text { Slightly vesicular gray-brown aphyric rock with small angular vesicles; cuttings coated with } \\
\text { microphenocrysts of plagioclase, olivine, and possibly pyroxene; clay present with manganese } \\
\text { staining }\end{array}$ \\
\hline 252 & to & 247 & 730 & to & 735 & $\begin{array}{l}\text { Slightly vesicular gray-brown aphyric rock with small angular vesicles; cuttings coated with } \\
\text { microphenocrysts of plagioclase, olivine, and possibly pyroxene; clay present with manganese } \\
\text { staining }\end{array}$ \\
\hline 247 & to & 242 & 735 & to & 740 & $\begin{array}{l}\text { Slightly vesicular gray-brown aphyric rock with small angular vesicles; cuttings coated with } \\
\text { microphenocrysts of plagioclase, olivine, and possibly pyroxene; clay present with manganese } \\
\text { staining }\end{array}$ \\
\hline 242 & to & 237 & 740 & to & 745 & Dense nonvesicular reddish brown rock; sparse olivine phenocrysts \\
\hline 237 & to & 232 & 745 & to & 750 & Dense vesicular reddish brown rock with angular vesicles; sparse olivine phenocrysts \\
\hline 232 & to & 227 & 750 & to & 755 & Dense vesicular reddish-brown rock with angular vesicles; sparse olivine phenocrysts \\
\hline 227 & to & 222 & 755 & to & 760 & Dark gray sand-size cuttings \\
\hline 222 & to & 217 & 760 & to & 765 & Dense dark gray rock; phenocrysts of olivine $\sim 1.0 \mathrm{~mm}$ across \\
\hline 217 & to & 212 & 765 & to & 770 & Dense dark gray aphyric rock \\
\hline 212 & to & 207 & 770 & to & 775 & Dense dark gray aphyric rock \\
\hline 207 & to & 202 & 775 & to & 780 & Dense dark gray rock; sparse phenocrysts of plagioclase \\
\hline 202 & to & 197 & 780 & to & 785 & Dense slightly weathered dark gray aphyric rock \\
\hline 197 & to & 192 & 785 & to & 790 & Slightly weathered dense dark gray aphyric rock \\
\hline 192 & to & 187 & 790 & to & 795 & Slightly weathered dense dark gray aphyric rock \\
\hline
\end{tabular}


Table 3. Lithologic descriptions of rock cuttings from the Kualapuu deep monitor well (4-0800-01), Molokai, Hawaii--Continued [Datum is mean sea level; depth measured from 982 feet above sea level; mm, millimeter; <, less than; <<, much less than; , about; samples were collected every 5 feet, but the actual depth from which the samples originated is not well known; many of the samples contain a mixture of several volcanic-rock morphologies]

\begin{tabular}{|c|c|c|c|c|c|c|}
\hline \multicolumn{3}{|c|}{$\begin{array}{l}\text { Elevation } \\
\text { (feet) }\end{array}$} & \multicolumn{3}{|c|}{$\begin{array}{l}\text { Depth } \\
\text { (feet) }\end{array}$} & \multirow{2}{*}{$\begin{array}{l}\text { Sample description } \\
\text { Red-brown weathered rock with angular vesicles }\end{array}$} \\
\hline 187 & to & 182 & 795 & to & 800 & \\
\hline 182 & to & 177 & 800 & to & 805 & $\begin{array}{l}\text { Mixture of dark gray nonvesicular aphyric rock and vesicular aphyric rock with angular vesicles } \\
\text { and round vesicles }\end{array}$ \\
\hline 177 & to & 172 & 805 & to & 810 & Slightly weathered gray rock; sparse phenocrysts of olivine and plagioclase \\
\hline 172 & to & 167 & 810 & to & 815 & Slightly weathered gray rock; sparse phenocrysts of olivine and plagioclase \\
\hline 167 & to & 162 & 815 & to & 820 & Slightly weathered gray rock; sparse phenocrysts of olivine and plagioclase \\
\hline 157 & to & 152 & 825 & to & 830 & $\begin{array}{l}\text { Mixture of dense brown aphyric rock with angular vesicles and vesicular gray aphyric rock with } \\
\text { round vesicles }\end{array}$ \\
\hline 152 & to & 147 & 830 & to & 835 & $\begin{array}{l}\text { Mixture of dense brown aphyric rock with angular vesicles and vesicular gray aphyric rock with } \\
\text { round vesicles }\end{array}$ \\
\hline 147 & to & 142 & 835 & to & 840 & Gray vesicular aphyric rock with round vesicles \\
\hline 127 & to & 122 & 855 & to & 860 & Brown scoriaceous rock with round vesicles \\
\hline 122 & to & 117 & 860 & to & 865 & Gray-brown vesicular aphyric rock with round vesicles \\
\hline 117 & to & 112 & 865 & to & 870 & Mixture of gray-brown rock with angular vesicles and dense aphyric rock \\
\hline 112 & to & 107 & 870 & to & 875 & Mixture of gray-reddish brown rock with angular vesicles and dense aphyric rock \\
\hline 107 & to & 102 & 875 & to & 880 & Mixture of gray-reddish brown rock with angular vesicles and dense aphyric rock \\
\hline 102 & to & 97 & 880 & to & 885 & $\begin{array}{l}\text { Mixture of brown scoriaceous rock with round vesicles and dense dark gray rock with angular } \\
\text { vesicles }\end{array}$ \\
\hline 97 & to & 92 & 885 & to & 890 & $\begin{array}{l}\text { Mixture of brown scoriaceous rock with round vesicles and dense dark gray rock with angular } \\
\text { vesicles }\end{array}$ \\
\hline 92 & to & 87 & 890 & to & 895 & Dense dark gray aphyric rock with round vesicles \\
\hline 87 & to & 82 & 895 & to & 900 & Weathered gray-brown rock with sub-angular vesicles \\
\hline 82 & to & 77 & 900 & to & 905 & Slightly weathered gray-brown rock with sub-angular vesicles \\
\hline 77 & to & 72 & 905 & to & 910 & Slightly weathered gray-brown rock with sub-angular vesicles \\
\hline 72 & to & 67 & 910 & to & 915 & Slightly weathered gray-brown rock with sub-angular vesicles \\
\hline 67 & to & 62 & 915 & to & 920 & Slightly weathered gray-brown rock with sub-angular vesicles \\
\hline 62 & to & 57 & 920 & to & 925 & $\begin{array}{l}\text { Mixture of gray-brown rock with round vesicles and dense dark gray aphyric rock with angular } \\
\text { vesicles }\end{array}$ \\
\hline 57 & to & 52 & 925 & to & 930 & $\begin{array}{l}\text { Mixture of gray-brown rock with round vesicles and sparse plagioclase phenocrysts and dense } \\
\text { dark gray aphyric rock with angular vesicles }\end{array}$ \\
\hline 52 & to & 47 & 930 & to & 935 & $\begin{array}{l}\text { Mixture of gray-brown rock with round vesicles and sparse plagioclase phenocrysts and dense } \\
\text { dark gray aphyric rock with angular vesicles }\end{array}$ \\
\hline 47 & to & 42 & 935 & to & 940 & Weathered gray-brown rock with round vesicles \\
\hline 42 & to & 37 & 940 & to & 945 & $\begin{array}{l}\text { Weathered gray-brown rock with sub-angular vesicles containing sparse plagioclase phenocrysts } \\
<1.0 \mathrm{~mm} \text { across }\end{array}$ \\
\hline 37 & to & 32 & 945 & to & 950 & Weathered gray-brown rock with sub-angular vesicles \\
\hline 32 & to & 27 & 950 & to & 955 & $\begin{array}{l}\text { Mixture of gray aphyric rock with round vesicles and dense aphyric gray rock with angular vesi- } \\
\text { cles }\end{array}$ \\
\hline 27 & to & 22 & 955 & to & 960 & Weathered brown aphyric rock with round vesicles \\
\hline 22 & to & 17 & 960 & to & 965 & Weathered gray-brown aphyric rock with round vesicles \\
\hline 17 & to & 12 & 965 & to & 970 & Weathered gray-brown aphyric scoriaceous rock with round vesicles \\
\hline 12 & to & 7 & 970 & to & 975 & Weathered gray-brown aphyric scoriaceous rock with round vesicles \\
\hline 7 & to & 2 & 975 & to & 980 & Weathered brown aphyric rock with round vesicles \\
\hline 2 & to & -3 & 980 & to & 985 & $\begin{array}{l}\text { Mixture of gray aphyric rock with round vesicles and dense aphyric gray rock with angular vesi- } \\
\text { cles }\end{array}$ \\
\hline-3 & to & -8 & 985 & to & 990 & Dark brown scoriaceous aphyric rock with round vesicles \\
\hline-8 & to & -13 & 990 & to & 995 & Dark reddish brown scoriaceous aphyric rock with round vesicles \\
\hline-13 & to & -18 & 995 & to & 1,000 & Dark gray aphyric rock with round vesicles \\
\hline
\end{tabular}


Table 3. Lithologic descriptions of rock cuttings from the Kualapuu deep monitor well (4-0800-01), Molokai, Hawaii--Continued [Datum is mean sea level; depth measured from 982 feet above sea level; mm, millimeter; <, less than; <<, much less than; , about; samples were collected every 5 feet, but the actual depth from which the samples originated is not well known; many of the samples contain a mixture of several volcanic-rock morphologies]

\begin{tabular}{|c|c|c|c|c|c|}
\hline \multicolumn{3}{|c|}{$\begin{array}{l}\text { Elevation } \\
\text { (feet) }\end{array}$} & \multicolumn{2}{|c|}{$\begin{array}{l}\text { Depth } \\
\text { (feet) }\end{array}$} & \multirow[t]{2}{*}{ Sample description } \\
\hline-18 & to & -23 & 1,000 & to 1,005 & \\
\hline-23 & to & -28 & 1,005 & to 1,010 & Gray aphyric rock with round vesicles \\
\hline-28 & to & -33 & 1,010 & to 1,015 & $\begin{array}{l}\text { Mixture of gray aphyric rock with round vesicles and dense aphyric gray rock with angular vesi- } \\
\text { cles }\end{array}$ \\
\hline-33 & to & -38 & 1,015 & to 1,020 & $\begin{array}{l}\text { Mixture of gray aphyric rock with round vesicles and dense aphyric gray rock with angular vesi- } \\
\text { cles }\end{array}$ \\
\hline-38 & to & -43 & 1,020 & to 1,025 & Brown scoriaceous aphyric rock with round vesicles \\
\hline-43 & to & -48 & 1,025 & to 1,030 & $\begin{array}{l}\text { Mixture of red, gray, and brown rock with sub-angular vesicles containing sparse plagioclase, } \\
\text { olivine, and possibly pyroxene phenocrysts and dense gray aphyric rock }\end{array}$ \\
\hline-48 & to & -53 & 1,030 & to 1,035 & $\begin{array}{l}\text { Mixture of red, gray, and brown rock with sub-angular vesicles containing sparse plagioclase } \\
\text { microphenocrysts and dense gray aphyric rock }\end{array}$ \\
\hline-53 & to & -58 & 1,035 & to 1,040 & $\begin{array}{l}\text { Mixture of red, gray, and brown rock with sub-angular vesicles containing sparse plagioclase } \\
\text { microphenocrysts and dense gray rock containing sparse olivine phenocrysts }\end{array}$ \\
\hline-58 & to & -63 & 1,040 & to 1,045 & $\begin{array}{l}\text { Mixture of red, gray, and brown rock with sub-angular to angular vesicles containing sparse pla- } \\
\text { gioclase microphenocrysts and dense gray rock containing sparse olivine phenocrysts }\end{array}$ \\
\hline-63 & to & -68 & 1,045 & to 1,050 & $\begin{array}{l}\text { Gray to dark gray rock with angular vesicles containing sparse olivine and plagioclase pheno- } \\
\text { crysts }<1.0 \mathrm{~mm} \text { across }\end{array}$ \\
\hline-68 & to & -73 & 1,050 & to 1,055 & Mixture of dark gray aphyric rock with round vesicles and dense gray aphyric rock \\
\hline-73 & to & -78 & 1,055 & to 1,060 & Gray scoriaceous rock with many round vesicles containing sparse olivine phenocrysts \\
\hline-78 & to & -83 & 1,060 & to 1,065 & $\begin{array}{l}\text { Mixture of dark gray rock with round vesicles containing sparse plagioclase phenocrysts and } \\
\text { dense gray rock with sparse plagioclase phenocrysts }\end{array}$ \\
\hline-83 & to & -88 & 1,065 & to 1,070 & $\begin{array}{l}\text { Mixture of dark gray and brown rock with round vesicles containing sparse plagioclase pheno- } \\
\text { crysts and dense gray rock with sparse plagioclase phenocrysts }\end{array}$ \\
\hline-88 & to & -93 & 1,070 & to 1,075 & $\begin{array}{l}\text { Mixture of dark gray and brown rock with sub-angular vesicles containing sparse plagioclase } \\
\text { phenocrysts and dense gray rock with sparse plagioclase phenocrysts }\end{array}$ \\
\hline-93 & to & -98 & 1,075 & to 1,080 & $\begin{array}{l}\text { Mixture of dark gray and brown rock with sub-angular vesicles containing sparse plagioclase } \\
\text { phenocrysts and dense gray rock with sparse plagioclase phenocrysts }\end{array}$ \\
\hline-98 & to & -103 & 1,080 & to 1,085 & $\begin{array}{l}\text { Mixture of dark gray and brown rock with sub-angular vesicles containing sparse plagioclase } \\
\text { phenocrysts and dense gray rock with sparse plagioclase phenocrysts }\end{array}$ \\
\hline-103 & to & -108 & 1,085 & to 1,090 & $\begin{array}{l}\text { Mixture of dark gray and brown rock with sub-angular vesicles containing sparse plagioclase } \\
\text { phenocrysts and dense gray rock with sparse plagioclase phenocrysts }\end{array}$ \\
\hline-108 & to & -113 & 1,090 & to 1,095 & $\begin{array}{l}\text { Mixture of dark gray and brown and weathered rock with sub-angular vesicles containing sparse } \\
\text { plagioclase phenocrysts and dense gray rock with sparse plagioclase phenocrysts }\end{array}$ \\
\hline-113 & to & -118 & 1,095 & to 1,100 & $\begin{array}{l}\text { Mixture of dark gray-brown scoriaceous rock with round vesicles containing sparse plagioclase } \\
\text { phenocrysts and dense gray aphyric rock }\end{array}$ \\
\hline-118 & to & -123 & 1,100 & to 1,105 & $\begin{array}{l}\text { Mixture of dark gray-brown scoriaceous rock with round vesicles containing sparse plagioclase } \\
\text { phenocrysts and dense gray aphyric rock }\end{array}$ \\
\hline-123 & to & -128 & 1,105 & to 1,110 & Gray rock with angular vesicles containing sparse plagioclase phenocrysts \\
\hline-128 & to & -133 & 1,110 & to 1,115 & Gray rock with angular vesicles containing sparse plagioclase phenocrysts \\
\hline-133 & to & -138 & 1,115 & to 1,120 & $\begin{array}{l}\text { Mixture of red-brown and gray scoriaceous rock with round vesicles and containing plagioclase } \\
\text { and olivine phenocrysts and dense slightly weathered aphyric rock }\end{array}$ \\
\hline-138 & to & -143 & 1,120 & to 1,125 & No sample collected \\
\hline-143 & to & -148 & 1,125 & to 1,130 & $\begin{array}{l}\text { Mixture of dark gray scoriaceous rock with round vesicles and gray rock with angular vesicles } \\
\text { containing plagioclase phenocrysts }\end{array}$ \\
\hline-148 & to & -153 & 1,130 & to 1,135 & $\begin{array}{l}\text { Mixture of dark gray scoriaceous rock with round vesicles containing phenocrysts of olivine and } \\
\text { plagioclase and gray rock with angular vesicles }\end{array}$ \\
\hline-153 & to & -158 & 1,135 & to 1,140 & $\begin{array}{l}\text { Mixture of dark gray scoriaceous rock with round vesicles and gray rock with angular vesicles } \\
\text { containing plagioclase phenocrysts }\end{array}$ \\
\hline-158 & to & -163 & 1,140 & to 1,145 & Slightly weathered light gray rock with angular vesicles \\
\hline-163 & to & -168 & 1,145 & to 1,150 & Slightly weathered light gray rock with angular vesicles \\
\hline-168 & to & -173 & 1,150 & to 1,155 & $\begin{array}{l}\text { Mixture of dense gray and vesicular rock with angular vesicles containing sparse plagioclase } \\
\text { laths }<1.0 \mathrm{~mm} \text { long }\end{array}$ \\
\hline-173 & to & -178 & 1,155 & to 1,160 & $\begin{array}{l}\text { Mixture of dense gray and vesicular rock with angular vesicles containing sparse plagioclase } \\
\text { laths }<1.0 \mathrm{~mm} \text { long }\end{array}$ \\
\hline-178 & to & -183 & 1,160 & to 1,165 & Mixture of aphyric dense gray and vesicular rock with angular vesicles \\
\hline
\end{tabular}


Table 3. Lithologic descriptions of rock cuttings from the Kualapuu deep monitor well (4-0800-01), Molokai, Hawaii--Continued [Datum is mean sea level; depth measured from 982 feet above sea level; mm, millimeter; <, less than; <<, much less than; , about; samples were collected every 5 feet, but the actual depth from which the samples originated is not well known; many of the samples contain a mixture of several volcanic-rock morphologies]

\begin{tabular}{|c|c|c|c|c|c|}
\hline \multicolumn{3}{|c|}{$\begin{array}{l}\text { Elevation } \\
\text { (feet) }\end{array}$} & \multicolumn{2}{|c|}{$\begin{array}{l}\text { Depth } \\
\text { (feet) }\end{array}$} & Sample description \\
\hline-183 & to & -188 & 1,165 & to 1,170 & $\begin{array}{l}\text { Mixture of dense gray and vesicular rock with angular vesicles containing sparse micropheno- } \\
\text { crysts of plagioclase and olivine }\end{array}$ \\
\hline-193 & to & -198 & 1,175 & to 1,180 & Dense gray aphyric rock with round to sub-angular vesicles \\
\hline-198 & to & -203 & 1,180 & to 1,185 & $\begin{array}{l}\text { Dense gray aphyric rock with round to sub-angular vesicles containing sparse plagioclase phe- } \\
\text { nocrysts }\end{array}$ \\
\hline-208 & to & -213 & 1,190 & to 1,195 & $\begin{array}{l}\text { Mixture of red-brown clinkery rock with small angular vesicles and containing plagioclase and } \\
\text { olivine phenocrysts and dense gray rock containing plagioclase phenocrysts }\end{array}$ \\
\hline-213 & to & -218 & 1,195 & to 1,200 & Gray rock with angular vesicles containing microphenocrysts of plagioclase and olivine \\
\hline-218 & to & -223 & 1,200 & to 1,205 & $\begin{array}{l}\text { Mixture of brown to dark gray rock with round vesicles containing microlaths of plagioclase and } \\
\text { dense aphyric gray rock }\end{array}$ \\
\hline-223 & to & -228 & 1,205 & to 1,210 & Brown-gray rock with round vesicles containing microphenocrysts of olivine \\
\hline-243 & to & -248 & 1,225 & to 1,230 & $\begin{array}{l}\text { Mixture of gray-brown rock with angular vesicles and dense rock containing sparse plagioclase } \\
\text { phenocrysts }\end{array}$ \\
\hline-248 & to & -253 & 1,230 & to 1,235 & $\begin{array}{l}\text { Mixture of gray-brown rock with angular vesicles and dense rock containing sparse plagioclase } \\
\text { microphenocrysts }\end{array}$ \\
\hline-253 & to & -258 & 1,235 & to 1,240 & $\begin{array}{l}\text { Mixture of gray-brown rock with angular vesicles and dense rock containing sparse microphe- } \\
\text { nocrysts of plagioclase and olivine }\end{array}$ \\
\hline-258 & to & -263 & 1,240 & to 1,245 & $\begin{array}{l}\text { Mixture of gray-brown rock with angular vesicles and dense rock containing sparse microphe- } \\
\text { nocrysts of plagioclase and olivine }\end{array}$ \\
\hline-263 & to & -268 & 1,245 & to 1,250 & Mixture of gray-brown rock with angular vesicles and dense aphyric rock \\
\hline-268 & to & -273 & 1,250 & to 1,255 & $\begin{array}{l}\text { Mixture of gray-brown rock with angular vesicles and dense rock with sparse phenocrysts, possi- } \\
\text { bly pyroxene }\end{array}$ \\
\hline-273 & to & -278 & 1,255 & to 1,260 & $\begin{array}{l}\text { Mixture of gray-brown rock with angular vesicles and dense rock with sparse phenocrysts of pla- } \\
\text { gioclase and possibly pyroxene }\end{array}$ \\
\hline-303 & to & -308 & 1,285 & to 1,290 & $\begin{array}{l}\text { Mixture of scoriaceous glassy rock with round to sub-angular vesicles and dense gray rock with } \\
\text { angular vesicles }\end{array}$ \\
\hline-308 & to & -313 & 1,290 & to 1,295 & $\begin{array}{l}\text { Mixture of scoriaceous glassy rock with round to sub-angular vesicles and dense gray rock with } \\
\text { angular vesicles containing sparse olivine and plagioclase phenocrysts }<1.0 \mathrm{~mm} \text { across }\end{array}$ \\
\hline-313 & to & -318 & 1,295 & to 1,300 & $\begin{array}{l}\text { Mixture of scoriaceous glassy rock with round to sub-angular vesicles and dense gray rock with } \\
\text { angular vesicles containing sparse plagioclase phenocrysts }<1.0 \mathrm{~mm} \text { across }\end{array}$ \\
\hline-318 & to & -323 & 1,300 & to 1,305 & $\begin{array}{l}\text { Mixture of dark gray-brown rock with angular vesicles and dense gray rock; some vesicles con- } \\
\text { tain white clay }\end{array}$ \\
\hline-323 & to & -328 & 1,305 & to 1,310 & $\begin{array}{l}\text { Mixture of dark gray-brown rock with angular vesicles and dense gray rock containing sparse } \\
\text { olivine phenocrysts }\end{array}$ \\
\hline-328 & to & -333 & 1,310 & to 1,315 & $\begin{array}{l}\text { Mixture of dark gray-brown rock with angular vesicles and dense gray rock containing sparse } \\
\text { olivine and plagioclase phenocrysts }\end{array}$ \\
\hline-333 & to & -338 & 1,315 & to 1,320 & $\begin{array}{l}\text { Dark gray to red-brown rock with angular vesicles containing microphenocrysts of olivine and } \\
\text { plagioclase }\end{array}$ \\
\hline-338 & to & -343 & 1,320 & to 1,325 & $\begin{array}{l}\text { Dark gray to red-brown rock with angular vesicles containing microphenocrysts of olivine and } \\
\text { plagioclase }\end{array}$ \\
\hline-343 & to & -348 & 1,325 & to 1,330 & Dark gray to red-brown rock with angular vesicles \\
\hline
\end{tabular}


Table 3. Lithologic descriptions of rock cuttings from the Kualapuu deep monitor well (4-0800-01), Molokai, Hawaii--Continued [Datum is mean sea level; depth measured from 982 feet above sea level; mm, millimeter; <, less than; <<, much less than; , about; samples were collected every 5 feet, but the actual depth from which the samples originated is not well known; many of the samples contain a mixture of several volcanic-rock morphologies]

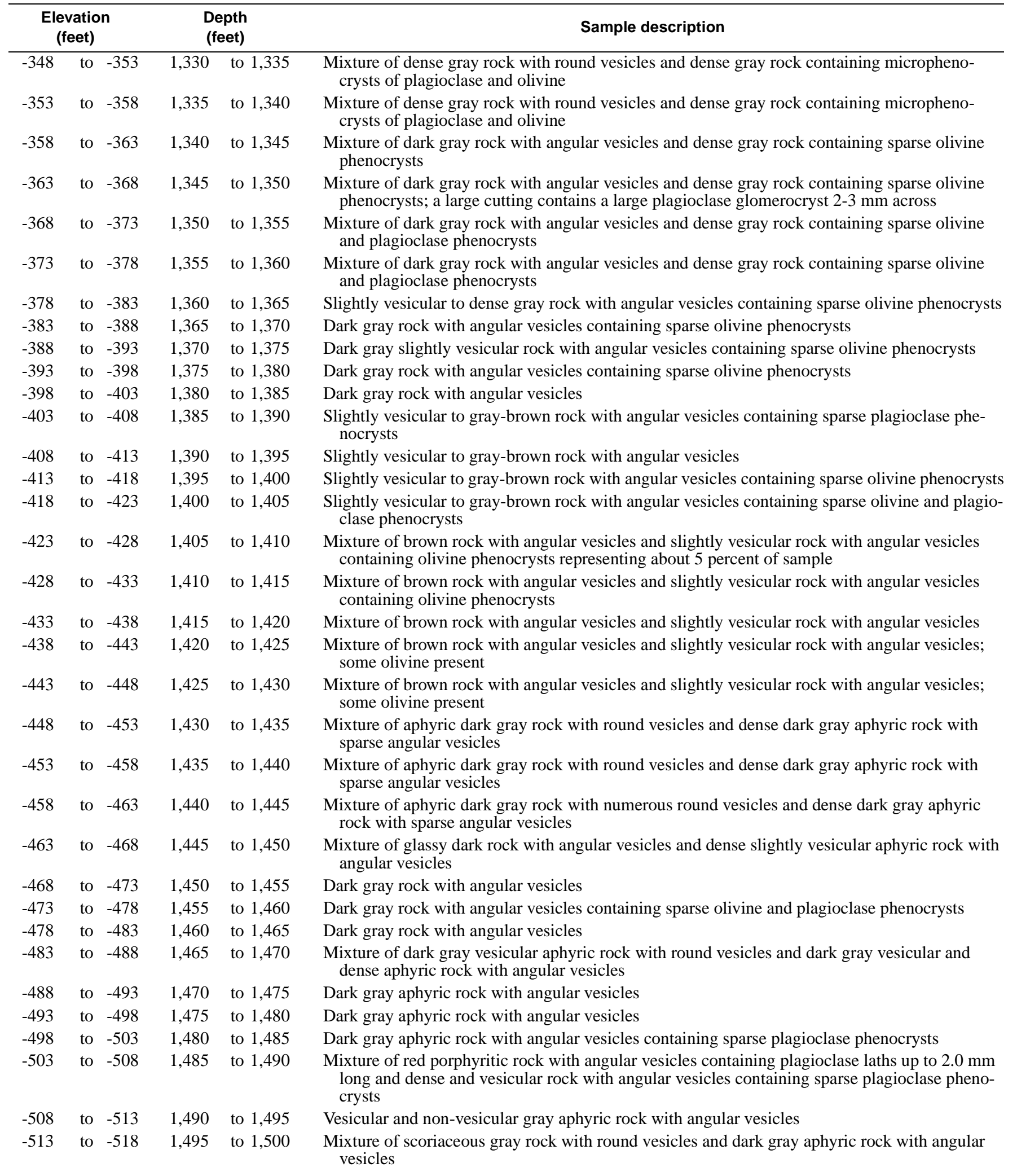


Table 3. Lithologic descriptions of rock cuttings from the Kualapuu deep monitor well (4-0800-01), Molokai, Hawaii--Continued [Datum is mean sea level; depth measured from 982 feet above sea level; mm, millimeter; <, less than; <<, much less than; , about; samples were collected every 5 feet, but the actual depth from which the samples originated is not well known; many of the samples contain a mixture of several volcanic-rock morphologies]

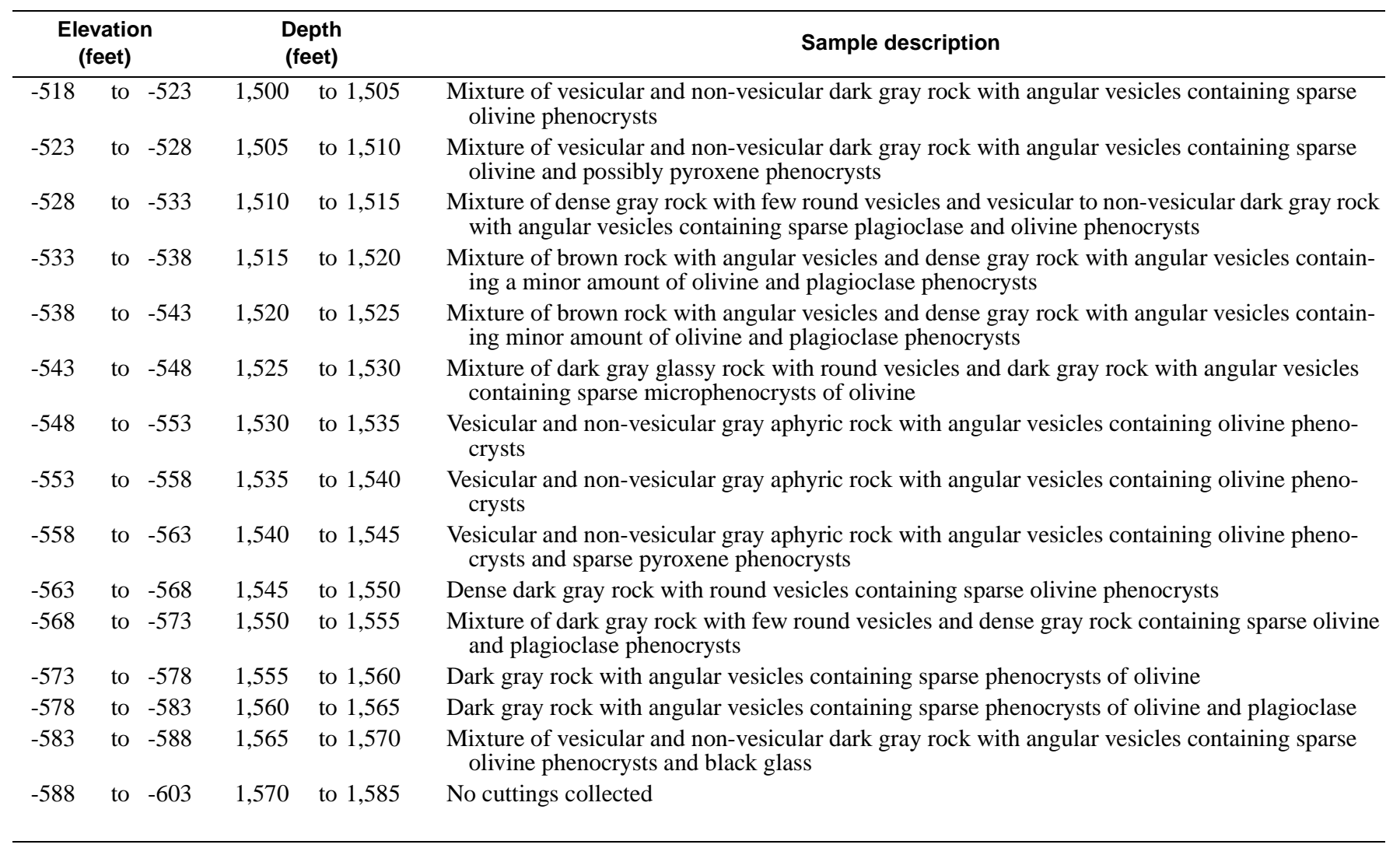

